\title{
Radiocarbon dating of burials from the Teouma Lapita cemetery, Efate, Vanuatu.
}

Fiona Petchey ${ }^{1}$, Matthew Spriggs, ${ }^{2}$ Stuart Bedford, ${ }^{3}$ Frédérique Valentin, ${ }^{4}$ Hallie Buckley. ${ }^{5}$ Radiocarbon Dating Laboratory, University of Waikato, Hamilton, New Zealand. 006478384278

fpetchey@waikato.ac.nz

School of Archaeology and Anthropology, The Australian National University, Canberra, ACT 0200, Australia.

Archaeology and Natural History, School of Culture, History and Language, The Australian National University, Canberra, ACT 0200, Australia.

CNRS, UMR7041, Paris 1 and 10, 92023 Nanterre, France.

Otago School of Medical Sciences, University of Otago, PO Box 913, Dunedin, New Zealand.

\section{ABSTRACT}

The discovery of a cemetery at Teouma on the island of Efate in Vanuatu dated to c. 3000 years ago increased the number of early Pacific human remains available for study by nearly an order of magnitude and provided for the first time the ability to study the population dynamics of these early colonizers. The cemetery also provided an opportunity to investigate the chronological development of such a unique site. Although identified short-lived plant materials are favoured for dating archaeological sites, the reality of research in the Pacific region is that such materials are often rare, difficult to identify to species because of an absence of suitable reference collections, and dates on other materials often have greater potential to refine and focus ${ }^{14} \mathrm{C}$ chronologies that deal with specific research questions. At Teouma, dates on the burial remains themselves are the best means to answer questions about the age and duration of the burial ground. Human bone, however, is one of the most complicated materials to date reliably because of dietary ${ }^{14} \mathrm{C}$ offsets and bone preservation. One commonly used methodology for calibrating dates on human bone from Pacific human skeletal remains, based on linear interpolation between $\delta^{13} \mathrm{C}$ endpoints and $\delta^{15} \mathrm{~N}$ values, is complicated by the wide range of foods available (marine, reef, $\mathrm{C}_{4}$ and $\mathrm{C}_{3}$ ), and remains largely untested in Pacific contexts. Radiocarbon dating of the Teouma site, including 36 Lapita-age burials, 5 dates on Conus sp. ring artefacts, and dates from the associated midden deposit, has enabled further evaluation of ${ }^{14} \mathrm{C}$ dietary offsets and the reliability of calibrated radiocarbon ages on human bone. Bayesian evaluation of the ${ }^{14} \mathrm{C}$ dates suggests the burial ground was in regular use by c. 2940-2880 cal BP, with the last interments occurring c. 2770-2710 cal BP. A number of burials could indicate possible earlier use, perhaps as early as 3110-2930 cal BP as indicated by the calibrated age range of Burial 57 . This cannot be independently substantiated using other radiocarbon dates or context at the present time. Overall, these results suggest the burial ground was in use over a possible 150 to 240 years during the formative phase of Lapita expansion into Remote Oceania.

KEYWORDS: Calibration, diet, human bone, Lapita, radiocarbon, stable isotopes, Teouma.

\section{INTRODUCTION}

The Teouma site is located on the south coast of Efate Island, Vanuatu, $800 \mathrm{~m}$ from Teouma Bay (Figure 1). Excavations took place between 2004 and 2010 (Bedford 2006; Bedford et al. 2009, 
2010) during which 68 single and multiple burials, concentrated in a band running northeast to southwest, parallel to the former beach, were uncovered. There are essentially two key zones of the site that are considered in this analysis: the Cemetery Zone and the Midden Zone (primarily the Area 2B extension) located to the east of the cemetery. Layer 3 of the Midden Zone deposit was considered to be contemporary with the cemetery use since it largely respected the cemetery boundary and contained substantial amounts of extinct fauna and obsidian from the Willaumez Peninsular deposited on top of an orange/yellow tephra (Spriggs and Bedford 2013). Layer 2 of the Midden Zone seems to have been contemporary with cemetery but also likely associated with subsequent Lapita midden dumping that extended on top of the cemetery (i.e., Cemetery Zone Layer $2 / 3$ transition). A later midden deposit of up to $50 \mathrm{~cm}$ thick capped the Lapita cemetery area and is associated with the Arapus and Early Erueti phases currently dated to c. 2800-2500 BP (Bedford et al. 2009:219-221). Layer 1 of both zones represents natural post-occupation accumulation, rich in tephra, but also some earlier material brought up from lower levels of the site.

Preliminary analysis of the Lapita ceramics places most of them in the Western or Middle Lapita style with hints of Early Far Western and Late/Eastern styles. A mix of older styles, exotic ceramics combined with more simplified dentate-stamped design, and later incised and shell impression wares support the hypothesis that Teouma represents an early phase of expansion into Remote Oceania with some continued interaction in the region for several hundred years (Bedford et al. 2009:225-6). Bayesian analysis of 38 radiocarbon dates on a mix of shell, charcoal and terrestrial animal bones suggest the Area 2 and 2B Lapita midden deposits and cemetery began shortly after 3000 cal BP (unpublished data). Bedford et al. (2009:221; 2010) suggested that the cemetery was used for only a short period of time based on re-deposition of human remains, similarity of mortuary practice across the site and limited inter-cutting of burials (Valentin et al. 2010a). The measurement of 36 radiocarbon dates on the burials themselves was hoped to confirm this, but further investigation of potential dietary offsets was necessary before any chronological evaluation could be made.

\subsection{Dietary Correction}

Ever-increasing improvements to the precision of radiocarbon measurement, combined with improved knowledge of sample type issues and routine statistical modelling have highlighted our limited understanding of ${ }^{14} \mathrm{C}$ variation in nature. Of particular concern is that humans and domestic omnivorous animals, such as pigs, can have a diet consisting of both marine and terrestrial foods. Because these two ${ }^{14} \mathrm{C}$ reservoirs differ by around $400{ }^{14} \mathrm{C}$ years it is essential that the correct proportions of each ${ }^{14} \mathrm{C}$ calibration curve are used when calculating a calendar age (i.e., SHCal13 [Hogg et al. 2013]/IntCal13 and Marine13 [Reimer et al. 2013]). $\delta^{13} \mathrm{C}$ and/or $\delta^{15} \mathrm{~N}$ isotopic values from bone protein are regularly used as indicators of different dietary protein sources, and are particularly useful in distinguishing marine and terrestrial protein diets (e.g., Ambrose and Norr 1993; Dewar and Pfeiffer 2010; Field et al. 2009; Richards et al. 2009; Tiezen and Fagre 1993; Valentin et al. 2010b). This is based on the fact that natural variations in $\delta^{13} \mathrm{C}$ values among plants and animals are maintained within the consumer bone collagen and that offsets between diet and consumer isotopic ratios, caused by metabolic fractionation, are relatively predictable. For temperate regions, consumer $\delta^{13} \mathrm{C}$ is generally enriched by $+5.0 \%$ o relative to plants consumed, and by $+1.0 \%$ relative to animals consumed (DeNiro and Epstein 1978; Fischer et al. 2007:2127; Lamb et al. 2012; Reitsema et al. 2010; van der Merwe and Vogel 1978; van Klinken et al. 2000). The mean $\delta^{13} \mathrm{C}$ for $\mathrm{C}_{3}$ plants is around $-26 \%$, while for $\mathrm{C}_{4}$ plants it is $-12 \%$. 
$\delta^{13} \mathrm{C}$ values in the marine reservoir are more varied, but tend to range between $-15 \%$ and $-10 \%$ o (Lee Thorp et al. 2007; Schoeninger and DeNiro 1984). This information can be strengthened by the measurement of $\delta^{15} \mathrm{~N}$; there is an increase in $\delta^{15} \mathrm{~N}$ value of c. +2 to $5 \%$ o for each step (trophic level) up the food chain (Hedges and Reynard 2007:table 2; Schoeninger and DeNiro 1984). Since aquatic (i.e., marine and freshwater) food chains are longer than terrestrial counterparts, diets dominated by food from fresh and/or marine waters can often be distinguished from more terrestrial diets by elevated nitrogen values. Consequently, humans from temperate regions who get most of their protein from marine food typically have $\delta^{15} \mathrm{~N}$ values between +12 and $+22 \%$, while those that consume only terrestrial protein have $\delta^{15} \mathrm{~N}$ values ranging from +5 to $+12 \%$ o (Richards et al. 1998:1248).

In practice, the interpretation of diet is complicated by numerous assumptions that make it difficult to assign actual proportions to different foods (see Hedges and Reynard [2007] and Schulting and Richards [2002]), but for ${ }^{14} \mathrm{C}$ work it is essential that a \% marine value is calculated. This is less palatable to researchers investigating diet alone because this value may differ from the actual proportions of foods eaten, primarily because of preferential routing of protein rich foods to protein in the body. Ultimately, this may result in an overrepresentation of marine foods in the diet. Since radiocarbon calculations are based on the specific ${ }^{14} \mathrm{C} /{ }^{12} \mathrm{C}$ ratio of the material analysed, however, any dietary correction applied to a date of bone protein must be representative of the proportion of marine carbon incorporated into the collagen and not a correction based on the proportions of marine food relative to whole diet. To simplify the process ${ }^{14} \mathrm{C}$ researchers have utilized a linear extrapolation methodology between terrestrial and marine $\delta^{13} \mathrm{C}$ endpoints whereby bone collagen $\delta^{13} \mathrm{C}$ values for animals that consumed terrestrial $\mathrm{C}_{3}$ pathway plants, or the flesh of animals that fed on those plants, are around -20 to $-21 \%$, with some latitudinal changes caused by atmospheric $\mathrm{CO}_{2}$ variation and temperature (van Klinken et al. 2000:52-54). Marine endpoints are recognised as being more difficult to define, but a $\delta^{13} \mathrm{C}$ value of $\mathrm{c}$. $-12 \%$ is typically used in Northern Hemisphere ${ }^{14} \mathrm{C}$ research to indicate a diet that is high in marine protein (e.g., Richards and Hedges 1999:892; Schoeninger et al. 1983). This methodology has been used for calibrating human bone radiocarbon determinations from Pacific island locations (Petchey and Green 2005), but there are recognised limitations in such contexts and it has not been thoroughly tested (Petchey et al. 2011).

For Pacific burials the ability to resolve the marine ${ }^{14} \mathrm{C}$ contribution to the bone collagen via diet is essential, but complex because of a possible combination of marine, reef and freshwater foods, as well as $\mathrm{C}_{3}$ and $\mathrm{C}_{4}$ plants (e.g., grasses, sea-grass and seaweeds) which confuse both the $\delta^{13} \mathrm{C}$ and $\delta^{15} \mathrm{~N}$ isotopic signatures. These interpretive difficulties increase as diets diversify and domesticates enter the picture (e.g., Field et al. 2009; Jones and Quinn 2009; Petchey et al. 2011:37). Unfortunately, the recent use of a third isotope $\left(\delta^{34} S\right)$ aimed to counteract this (Leach et al. 1996, 2000, 2003; Petchey and Green 2005; Petchey et al. 2011; Richards et al., 2001) has met with varying success because of a possible sea spray effect (Beavan Athfield et al. 2008; Kinaston 2010) or the consumption of animals that browse in this coastal zone, such as pigs (Beavan Athfield et al. 2008), while the limestone geologies of many Pacific islands can also provide a source of ${ }^{34} \mathrm{~S}$ that mimics marine signatures (Clark and Fritz 2000:fig 6.1). This last fact may limit the usefulness of this approach to areas with no, or limited limestone bedrock; explaining the apparent success of this methodology in some locations (e.g., Kinaston et al. 2013a) but the difficulty of using $\delta^{34} \mathrm{~S}$ at Teouma where limestone cliffs surround the site ${ }^{1}$. Consequently, dual

${ }^{1} \delta^{34} \mathrm{~S}$ values obtained for the Teouma burials are given in Table 1 . The enriched values for these probably reflect environmental/geological conditions, rather than a high $\%$ marine protein diet as the values obtained were identical to fully terrestrial tortoise $\delta^{34} \mathrm{~S}$ values obtained at the site 
isotope methodologies persist (cf., Kinaston et al. 2013a, 2013b, 2014; Valentin et al. 2010b, 2011) which, despite a growing database of published Pacific food isotope values, have been difficult to verify and refine.

None of these methodological issues are unsolvable, but the level of chronological control needed to test and refine the ${ }^{14} \mathrm{C}$ corrections needed for human remains from Pacific locals has been lacking until now. Here we present radiocarbon and stable isotope results for 36 radiocarbon dates on Lapita-age human burials ${ }^{2}$ and 5 associated Conus sp. shell rings from Teouma and compare them with associated dates from the adjacent Area 2 and 2B Lapita midden.

\section{SAMPLE SELECTION AND MEASUREMENT}

Thirty-nine Teouma Lapita burials were selected for dating. These include burials from the upper beach (burials 4, 5, 40, 53, 58, 59, 65) and reef locations (burials 8, 10e, 14, 16, 17, 18, 22, 24, 25, 26, 29w, 30 [a, b, c] , 34, 38, 41, 43, 44, 48, 50, 51, 52, 54, 55, 56, 57, 60, 64, 66, 67) (Figure 2). The majority of burials are adults, with the exception of burials 22 and 59, which are adolescents, and infant burial 24. All burials except infant burial 24 were the product of a complicated and lengthy mortuary protocol that ultimately resulted in incomplete primary burials and burials composed of multiple individuals (Valentin et al. 2010a).

All bone dates were prepared and analysed at the University of Waikato Radiocarbon facility in New Zealand. Gelatin was extracted from each specimen using a modified Longin (1971) protocol, whereby the sample was decalcified in $2 \% \mathrm{w} / \mathrm{v} \mathrm{HCl}$ at $4^{\circ} \mathrm{C}$ for 24 hours, then rinsed with distilled water. This acid insoluble collagen was then gelatinised by heating in weakly acidic water ( $\mathrm{pH}=3$ at $90^{\circ} \mathrm{C}$ for 4 hours) and the supernatant ("gelatin") removed, ultrafiltered (cleaned Centriprep ${ }^{\circledR}$, Ultracel YM-30 filters), and freeze-dried (after Bronk-Ramsey et al. [2004]; UCI AMS [2006]). AMS targets were measured at the Keck Radiocarbon Laboratory, University of California, Irvine, or GNS Science, Wellington. $\delta^{13} \mathrm{C}$ values for ${ }^{14} \mathrm{C}$ fractionation correction were measured on gas splits taken during preparation of samples for AMS analysis at the University of Waikato using a Europa Scientific Penta 20-20 isotope ratio mass spectrometer (IRMS).

Gelatin stable isotope measurements used for dietary reconstruction and quality assurance (QA) were measured at Iso-trace Research Department of Chemistry, University of Otago on a Carlo Erba NA 1500 elemental analyser (EA), coupled with either a Europa Scientific '20/20 Hydra' or a Thermo Finnigan Delta Plus Advantage. Sulphur was measured at Isoprime Ltd, Manchester, using a Vario MICRO cube EA coupled to an Isoprime IRMS, or at Iso-Analytical, Crewe UK on a Roboprep EA coupled to a 20/20 IRMS. Bone isotope QA parameters (\% gelatin yield, \%,$\% \mathrm{C}$ and $\mathrm{C}: \mathrm{N}$ ) have been adapted specifically for ${ }^{14} \mathrm{C}$ use by van Klinken (1999), who noted that most well-preserved archaeological bone protein has a $\% \mathrm{~N}$ value that ranges between 11 and 16 , a $\% \mathrm{C}$ value between 30 and 45 , and a $\mathrm{C}: \mathrm{N}$ ratio range of $3.1-3.5^{3}$. Radiocarbon researchers have found that it is still possible for contaminated samples to give acceptable QA values therefore, following Brock et al. (2007), the amount of extractable protein (\% ultrafiltered gelatin yield) was also used as a guide to the reliability of the ${ }^{14} \mathrm{C}$ results, whereby any sample

(unpublished data). Kinaston (2010:129-132) lists the range of $\delta^{34} \mathrm{~S}$ for Pacific island remains as $6.1 \%$ - $15.4 \%$ for terrestrial systems and $16.9 \%$ - $19.5 \%$ for marine systems. However, there is insufficient variation to distinguish between $\mathrm{C}_{4}$ and marine offsets.

${ }^{2}$ In this evaluation we have excluded a radiocarbon date on cremation Burial 26 reported in Scott et al. (2010).

${ }^{3}$ This differs from Valentin et al. (2010b:1823) who used C:N parameters of 2.9-3.6 after DeNiro (1985). Independent evaluation of well-preserved bone stable isotopes at the Waikato Radiocarbon laboratory favour the parameters given by van Klinken (1999) for ${ }^{14} \mathrm{C}$ work. 
yielding $<0.5 \%$ of the starting weight of bone powder was treated with caution ${ }^{4}$. Stable isotope values and yield data are given in Table 1. An additional 33 stable isotope values were collated from Valentin et al. (2010b) and 9 tooth dentine and 13 bone collagen values from Kinaston (2010) and Kinaston et al. (2009). These values have been evaluated here according to the same parameters as outlined above. Calibrated radiocarbon dates and dietary parameters (per-cent marine carbon) are given in Table 2. The rationale behind our results is discussed in the following sections.

Four Conus sp. ring artefacts found in direct association with burials 4, 17, 58 and 59 have also been dated and provide control ${ }^{14} \mathrm{C}$ ages for our dietary corrected human bone results. A fifth radiocarbon date on a Conus sp. ring associated with undated Burial 11 was also obtained.

\section{RESULTS}

\subsection{Quality Assurance}

Twenty-one out of 58 (36\%) of the Kinaston (2010), Kinaston et al. (2009) and Valentin et al. (2010b) samples fall outside our very strict isotope QA parameters, compared to 0 out of 36 for the new dataset reported here. ${ }^{5}$ Of these 36 , five had low yield values $(<0.5 \%)$ and the associated ${ }^{14} \mathrm{C}$ data should therefore be treated with caution despite acceptable isotopic quality assurance values (Table 1). Yield information was not collected during the Kinaston (2010), Kinaston et al. (2009) and Valentin et al. (2010b) studies. The difference in acceptable sample numbers between the new data and Kinaston (2010), Kinaston et al. (2009) and Valentin et al. (2010b) datasets may be a consequence of specific pretreatment parameters (Petchey et al. 2011:37; Privat et al. 2007:1200) or bone selected (Martin et al. 1998). Regardless of the exact cause, which is beyond the scope of this paper, it does have an impact on the range of $\delta^{13} \mathrm{C}$ and $\delta^{15} \mathrm{~N}$ values used for dietary analysis.

Our $\delta^{13} \mathrm{C}$ values for the Lapita-age burials range from $-13.0 \%$ to $-16.5 \%$ with an average $\delta^{13} \mathrm{C}$ of $-15.2 \pm 0.8 \%$. $\delta^{15} \mathrm{~N}$ values range from $+10.6 \%$ to $+14.5 \%$ with an average value of $+12.4 \pm 0.8 \%$. The Valentin et al. (2010b), Kinaston (2010) and Kinaston et al. (2009) datasets have $\delta^{13} \mathrm{C}$ values that ranges from $-13.7 \%$ o to $-19.3 \%$ (average $=-15.9 \pm 1.2 \%$ ) and $\delta^{15} \mathrm{~N}$ from $+10.6 \%$ to $+16.1 \%$ (average $=+12.6 \pm 1.9 \%$ ). Removing samples that failed the QA tests reduces this range slightly $\left(\delta^{13} \mathrm{C}=-14 \%\right.$ to $-18.2 \%$; average $=15.9 \pm 1.1 \% ; \delta^{15} \mathrm{~N}=+10.6 \%$ o to $+15.2 \%$; average $=$ $+12.8 \pm 1.2 \%$ ). Combining all three datasets results in acceptable samples having an average $\delta^{13} \mathrm{C}$ of $-15.6 \pm 1.0 \%$ with a range between $-13.0 \%$ and $-18.2 \%$; average $\delta^{15} \mathrm{~N}=+12.6 \pm 1.2 \%$ and range from $+10.6 \%$ to $+15.2 \%$.

\subsection{Dietary Parameters}

As outlined above, considerable uncertainty exists with using $\mathrm{C}$ and $\mathrm{N}$ isotopes to arrive at an interpretation of dietary input. To counteract some of these issues it is generally recommended that reference isotopic data be collected from flora and fauna from the region and time period under

\footnotetext{
${ }^{4}$ This is lower than the cut off recommended by Brock et al. (2007). Rejecting samples that have less than $1 \%$ yield would result in most Pacific bones being excluded for radiocarbon dating. Research undertaken at the Waikato University Radiocarbon Laboratory indicates that bones returning a $0.5 \%$ yield give reliable results.

${ }^{5}$ Three bone samples submitted for analysis to Waikato were abandoned prior to isotopic testing due to poor quality gelatin and low yields. These include: Burial 64 (0.25\% gelatin yield); Burial 66 (0.07\% gelatin yield); and Burial 67 (0.25\% gelatin yield).
} 
study (Fischer et al. 2007:2140). Unfortunately, at present there is little comparative isotope data to which we can compare the Teouma burial remains. Here we have had to compromise by using the Pacific diet database (see Kinaston [2010] and Kinaston et al. [2013a]) compiled from both modern and prehistoric food sources (Figure 3). In Figure 3 we have taken the principal food source divisions and corrected them for a trophic shift in isotopic value between food source and consumer bone protein $\left(+1 \% \text { or for } \delta^{13} \mathrm{C},+5 \% \text { for } \delta^{13} \mathrm{C} \text { of plant food and }+3.5 \% \text { or } \delta^{15} \mathrm{~N}\right)^{6}$. These are overlain with available comparative food (marine turtle [?Chelonia mydas], tortoise [?Meiolania damelipi], rat [Rattus exulans], fruit bat [Pteropodidae], pig [Sus scrofa]) and human isotopes from Teouma (including the 37 acceptable values from Valentin et al. [2010b:1823, table 2] and Kinaston [2010:414, 415] and values published in Kinaston et al. [2014]).

The values presented in Figure 3 indicate that a fairly significant amount of marine protein has been incorporated into the bone protein of the Lapita-age individuals. $\delta^{13} \mathrm{C}$ values fall midway between terrestrial $\left(\mathrm{C}_{3}\right)$ /freshwater and marine/reef groupings. The Valentin/Kinaston isotopes display a greater spread towards terrestrial foods, while the new Waikato values fall closer to marine foods. Overall, $\delta^{15} \mathrm{~N}$ values range between $+10.6 \%$ to $+15.2 \%$, crossing the terrestrial/marine $\delta^{15} \mathrm{~N}$ boundary of $+12 \%$ established by Northern Hemisphere researchers (e.g., Richards et al. 1998:1248). Using Figure 3 as a guide, the potential $\delta^{13} \mathrm{C}$ endpoints are extremely broad (a terrestrial $\delta^{13} \mathrm{C}$ endpoint of c. $-20 \pm 2 \%$ and a marine $\delta^{13} \mathrm{C}$ endpoint of c. $-12.5 \pm 3 \%$ ). Although these endpoints are not dissimilar to that reported for the Northern hemisphere, and are statistically no different to the $\delta^{13} \mathrm{C}$ endpoints of $-21 \%$ and $-12 \%$ used by Petchey and Green (2005), the SD of the marine endpoint is too large to be useful for our purposes. Also of note is that the isotope values for pig from the Teouma midden generally reflect a more terrestrial $\mathrm{C}_{3}$ based omnivorous diet, in keeping with findings by Kinaston et al. 2014:13). Theoretically, it is possible that humans obtaining the majority of their dietary protein intake from these pigs could end up with an isotopic enrichment equivalent to that observed for some of the Lapita individuals, and therefore the actual marine ${ }^{14} \mathrm{C}$ input to the bone could be lower. This possibility, and the validity of the $\delta^{13} \mathrm{C}-21 \%$ o/-12\% endpoints, can be tested using radiocarbon dates on associated shell artefacts (see Diet 2 model in Table 2).

As an alternative to $\delta^{13} \mathrm{C}$ endpoints of $-21 \%$ and $-12 \%$ used by Petchey and Green (2005), Clark et al. (2013) have suggested isotopic endpoints of $-20 \%\left(C_{3}\right.$ terrestrial diet $)$ and c. $-10 \%$ o (marine diet) for omnivores from Pacific locations. These values are based on pigs found in archaeological sites across the Pacific, and the marine endpoint reflects the isotopic values obtained on animals with a demonstrably controlled and predominantly marine diet (Richards et al. 2009:36). In this dataset, $\delta^{15} \mathrm{~N}$ values for pigs eating only terrestrial protein fall between +7.0 and $+10.3 \%$, while those assumed to have a predominantly marine diet return values that fall between +14.4 and $+18.3 \%$ (see pig isotope band in Figure 2 ). Ultimately, the effect of using $\delta^{13} \mathrm{C}$ endpoints of $-20 \%$ and $-10 \%$ is a slightly reduced estimate of per-cent marine carbon in the bones (see Diet 1 model in Table 2).

The likelihood of $\mathrm{C}_{4}$ foods adds further complications to the dietary interpretation. The influence of $\mathrm{C}_{4}$ plants is possible via the ingestion of seaweed, both directly, and indirectly via marine animals (Kinaston 2010:332), and domesticated sugar cane (Kinaston et al. 2014:6). Most

\footnotetext{
${ }^{6}$ Our metabolic and tropic corrections to $\delta^{13} \mathrm{C}$ and $\delta^{15} \mathrm{~N}$ differ from those used in recent Pacific dietary publications; Kinaston et al. (2013a:907) assumed a diet-tissue enrichment in ${ }^{13} \mathrm{C}$ of $+5 \%$ and $+3 \%$ for $\delta^{15} \mathrm{~N}$ for burials from southern Papua New Guinea. Conversely, Valentin et al. $(2010 \mathrm{~b}, 2011)$ and Jones and Quinn (2009) corrected $\delta^{13} \mathrm{C}$ values by $+5 \%$ for $\delta^{13} \mathrm{C}$ and $\delta^{15} \mathrm{~N}$ for $+4 \%$ to arrive at consumer values for individuals from American Samoa, Teouma and Fiji respectively, while Allen and Craig (2009:490) used $+1 \%$ for $\delta^{13} \mathrm{C}$ and $+3 \% 0$ for $\delta^{15} \mathrm{~N}$ for individuals from the Cook Islands. Overall, there is considerable uncertainty about the magnitude of trophic level enrichment possible, and therefore variability in the protocols used by Pacific researchers.
} 
isotope studies (e.g., Valentin et al. 2006:1404; Richards et al. 2009:30) assume that the direct consumption by humans of $\mathrm{C}_{4}$ plants does not result in a significant shift in the $\delta^{13} \mathrm{C}$ values, except in extreme dietary situations, because plants contain almost no protein that can be preferentially routed to collagen. Isotopic analysis of human remains from several early archaeological sites in the Lau Island group (Jones and Quinn 2009:2750) and at Koné, New Caledonia (Petchey et al. 2011) have, however, returned depleted $\delta^{13} \mathrm{C}$ values interpreted as being from the consumption of $\mathrm{C}_{4}$ plants. One area that has not previously been explored to solve this problem in the Pacific is $\delta^{13} \mathrm{C}$ evaluation of bioapatite carbonates (enamel and bone carbonate). Bone carbonate $\delta^{13} \mathrm{C}$ value is a function of the bulk diet offset by around $+12 \%$ o to $+14 \%$ (Ambrose and Norr 1993; Tieszen and Fagre 1993). Consequently, for temperate region $\mathrm{C}_{3}$ browsers the $\delta^{13} \mathrm{C}$ values are around $12 \%$ o to $-14 \%$, while $\mathrm{C}_{4}$ grazers have values of around $0 \%$ to $+2 \%$, and predators closely resemble those of their prey (Lee Thorp et al. 2007). Kellner and Schoeninger (2007) used a combination of carbonate and collagen $\delta^{13} \mathrm{C}$ data to evaluate the contribution of $\mathrm{C}_{3}, \mathrm{C}_{4}$ and marine protein and energy sources in the diet. Using our collagen data, and 17 tooth enamel $\delta^{13} \mathrm{C}$ values (Table 1) from Bentley et al. (2007:653, figure 4) we have undertaken a similar analysis for the Teouma individuals. This evaluation has the caveat that tooth enamel once mineralized is not remodelled and therefore provides a record of diet history in early childhood (Ambrose and Norr 1993; Fremondeau et al. 2012).

Our results (Figure 4) show that the majority of the Teouma individuals studied fall on or near the marine protein regression line at the level of $100 \% \mathrm{C}_{3}$ energy. This indicates that most bone protein originates from marine protein sources, but that small amounts of $\mathrm{C}_{3}$ and $\mathrm{C}_{4}$ protein are possible in the diet. Bentley et al. (2007) previously identified three individuals (burials 3, 10e and 18) as foreigners on the basis of distinctive ${ }^{87} \mathrm{Sr} /{ }^{86} \mathrm{Sr}$ and $\delta^{18} \mathrm{O}$ values. ${ }^{7}$ In Figure 4 , burials 3 and 18 burials have higher proportions of energy contribution from $\mathrm{C}_{4}$ sources compared to many other individuals studied. Burial 18 appears to have a contribution from $\mathrm{C}_{3}$ protein sources but Burial 3 has a mixed marine/ $\mathrm{C}_{4}$ protein diet. This will result in an overestimation of the per-cent marine carbon value and could have a significant impact on the calibrated ${ }^{14} \mathrm{C}$ age range of Burial 3. Burial 8 falls below the $\mathrm{C}_{4}$ protein line, but a comparable $\delta^{13} \mathrm{C}$ value from Valentin et al. (2010b:Table 2) is more depleted $\left(\delta^{13} \mathrm{C}=-14.5 \%\right.$ ), so this cannot be confirmed. Ultimately, the identification of $\mathrm{C}_{4}$ protein in Burial 3 means any Teouma individuals not evaluated in this manner could have ${ }^{14} \mathrm{C}$ values that are offset, reducing the resolution of individual burial dates. The use of $\delta^{13} \mathrm{C}_{\text {carbonate }}$ to establish $\mathrm{C}_{4}$ dietary input requires further testing on Pacific examples.

\subsection{Radiocarbon evaluation}

All radiocarbon dates were calibrated and interpreted in a Bayesian framework using OxCal v4.2 (Bronk Ramsey 2013) with a mixture of the Marine13 and Intcal13 $3^{8}$ curves (Reimer et al. 2013) as determined from dietary terrestrial/marine isotopic endpoints; -20\%o/-10\%o (Diet 1) and -21\%o/$12 \%$ (Diet 2). Given the limitations of the dietary evaluation we have used an uncertainty of \pm 10 on the per-cent marine carbon result following the recommendations of Ambrose (1993:112), or

\footnotetext{
${ }^{7}$ Burial 10E identified by Bentley et al. (2007) as a foreigner has comparable isotope values to the majority of individuals from Teouma (Table 1).

${ }^{8}$ The ${ }^{14} \mathrm{C}$ division between the Northern and Southern Hemispheres is considered to lie along the Inter-tropical Convergence Zone (ITCZ). This creates additional uncertainty when calibrating terrestrial samples from Pacific locales because many island groups, including Vanuatu, straddle the South Pacific Convergence Zone, which merges with the ITCZ to the west. Because the Southern Hemisphere calibration curve (Hogg et al. 2013; McCormac et al. 2004) was developed from trees younger than 1000 cal BP collected above $25^{\circ} \mathrm{S}$ (South Africa $\left[25^{\circ} \mathrm{S}\right]$, New Zealand $\left[40^{\circ} \mathrm{S}\right.$ ] and Southern Chile $\left[55^{\circ} \mathrm{S}\right]$ ) we have opted to use the Northern Hemisphere calibration curve (IntCal13: Reimer et al., 2013) for terrestrial calibrations from Central Vanuatu $\left[\sim 17-18^{\circ} \mathrm{S}\right]$.
} 
\pm 20 for those burials identified as having a $\mathrm{C}_{4}$ dietary component (burials 3 and 18). For the mixed diet calculations and Conus sp. shell determinations ${ }^{9}$ a location-specific reservoir correction value $(\Delta \mathrm{R})$ of $40 \pm 44{ }^{14} \mathrm{C}$ years has been applied to the marine curve to adjust for regional oceanic variation in ${ }^{14} \mathrm{C}$ (Petchey et al. 2008:376-379). All dates given in the text are reported at $68.2 \%$ probability. To refine the chronological interpretation of Teouma we have utilized Bayesian statistical methods whereby ${ }^{14} \mathrm{C}$ ages are constrained by prior information such as stratigraphic sequence and archaeological provenance. The overall model is assessed by the calculation of an agreement index $\left(\mathrm{A}_{\text {model }}\right.$ or $\mathrm{A}_{\text {comb }}$ ) that tells us how well the model agrees with the observations. If "A" falls below $60 \%$ (equivalent to the $5 \%$ level of a $\chi^{2}$ test), the model should be re-evaluated (Bronk-Ramsey 1995).

Initially, we undertook a comparison of the ${ }^{14} \mathrm{C}$ results of the Conus sp. ring artefacts with the associated burial dates (burials 4, 17, 58 and 59) using the "combine" command in OxCal that enables the probability distributions of the two different dates to be assessed. This provided an independent check on the age of these individuals and our dietary assumptions. Our results (Table 3 ) show a good level of agreement between shell and bone results for Diet $2(-21 /-12 \%)$, but both

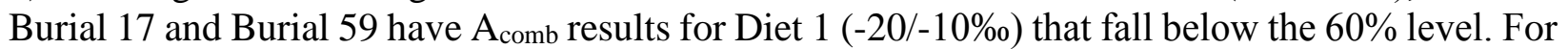
Burial $17\left(\mathrm{~A}_{\mathrm{comb}}=32.3\right)$ the associated shell result $(\mathrm{Wk}-37680)$ gives a calibrated age range that is younger $(2880-2750 \mathrm{cal} \mathrm{BP})$ than the associated burial ${ }^{14} \mathrm{C}$ result for this dietary model (3070$2960 \mathrm{cal}$ BP). A $\mathrm{A}_{\text {comb }}$ for Burial 59 is $54.6 \%$ with the shell returning a calibrated age of 2760-2650 cal BP compared to $2830-2750$ cal BP for the bone. The possibility that the Conus sp. shells may have some additional age (i.e., an "heirloom effect" where the artefacts may have been kept for some time before being deposited with each burial, or "inbuilt age" where older animals were selected) is unlikely as both of these scenarios would result in the Conus sp. dates being older than the date of deposition, which by implication would result in a smaller dietary correction being needed for the associated burial (therefore favouring the Diet 1 model). Instead, the slightly older age for Burial 17 may be a storage effect as this is a secondary burial (skull and mandible) subsequently placed on top of the Conus ring in a pot. However, based on the observations outlined above for both burial 17 and 59, we conclude that the higher per-cent marine carbon correction (Diet 2) is more appropriate. This value has been used for calibrated results given in Table 2 and Figure 5.

Because of the nature of cemetery sites it is rare to have stratigraphic information that can be used to refine the date sequence, and Teouma is no exception with limited intercutting of burials. Available archaeological evidence suggests the site was a single-phase cemetery that had been in use for a relatively short period of time. With the available information it is impossible to give a definitive start and end date for the Teouma cemetery because of uncertainties with dietary offsets, and because it is unclear whether we have dated the very first or very last individual interred there, though at least $75 \%$ of the cemetery has been excavated as its limits on three of four sides were established. Using a Bayesian framework we can however draw inference using the age of the material deposited between these two points. Based on field observations (Bedford et al. 2009, 2010) we initially combined all 36 burials and 5 shell dates into a single phase with a uniform

\footnotetext{
${ }^{9}$ There are some recognised uncertainties with dating shell, of note is the offset caused by regional marine reservoir variations (commonly referred to as $\Delta \mathrm{R}$ ). Conus are reef dwelling animals and are therefore not prone to ingestion of young terrestrial sediment as is the case for some estuarine shellfish (e.g. Anadara granosa [Petchey et al. 2013]). Limited studies on historic (pre-AD 1950) Conus sp. shells indicate they are in equilibrium with the marine $\mathrm{CaCO}_{3}$ (Petchey et al. 2008) and therefore expected to be comparable to the $\Delta \mathrm{R}$ value for Vanuatu used in this paper. $A \Delta \mathrm{R}$ for a single shell from Mangaia in the Cook Islands was tentatively attributed to the uptake of ${ }^{14} \mathrm{C}$ from the limestone bedrock, but this sample has less than ideal provenance information and a post-1950 date of collection. Moreover, $\delta^{13} \mathrm{C}$ values for the Conus sp. rings from burials 4, 17, 58 and 59 (range between 1.9 and $3.84 \%$ ) are all typical marine values (cf., Petchey et al. 2013).
} 
boundary using the OxCal sequence/boundary protocols. Unfortunately, OxCal was unable to resolve order regardless of per-cent marine carbon value used and the program run had to be abandoned. Substituting the uniform boundaries with trapezoidal priors (see Lee and Bronk Ramsey 2012) relaxed the boundary constraints and provided good agreement for both lower (Diet 1; A $_{\text {model }}=143.1$ ) and higher (Diet 2; Amodel $_{\text {192.9) }}$ per-cent marine carbon models (see Table 4). Trapezoidal priors enable a more gradual boundary transition to be incorporated into the model and therefore may better reflect the burial situation whereby the population would have expanded after initial settlement, plateaued, and then the cemetery would have gradually decreased in popularity as people moved away. It is also possible that a multiphase model may be more appropriate, but archaeological support for this possibility is not available. As indicated above, comparison of four burials with concomitant Conus sp. ${ }^{14} \mathrm{C}$ ages favours the higher per-cent marine carbon parameters (Diet 2) which results in slightly younger ages for the burials and suggests the cemetery was in regular use by c. 2940-2880 cal BP (possibly beginning as early as 2970 cal BP) with the last burial occurring c. $2770-2710 \mathrm{cal} \mathrm{BP}$, and possibly ending as late as $2680 \mathrm{cal} \mathrm{BP}$. Use of the Diet 1 model pushes the age of the cemetery back slightly to 3020-2950 cal BP, with the last regular activity occurring c. 2830-2760 cal BP (maximum age range of 3060-2710 cal BP). Overall the span of cemetery use falls between 150 and 240 years (Diet 2) or between 180 and 280 years (Diet 1) indicating use of this area for several generations (Table 4).

Radiocarbon dates on materials from the nearby Area 2 and 2B midden, including shortlived nut charcoal, marine shell, tortoise and chicken bones are also available for comparison. Stratigraphic interpretations made in the field indicated that Layers 2 and 3 from the Midden Zone were contemporary with the cemetery and that material from the Layer 2 Cemetery Zone midden belonged to immediately post-cemetery Arapus and Erueti phases. Intermixing between layers by post-cemetery human settlement activities has, however, resulted in numerous inversions that make the chronological interpretation less clear. Bayesian analysis of all Lapita deposits places them between c. 2960 and 2660 cal BP (unpublished data) - thus favouring a slightly younger age for the deposits than previously reported by Bedford et al. (2009). Assuming the midden and cemetery are of similar antiquity this result favours the slightly younger age range (2940-2710 cal $\mathrm{BP}$ ) for the burials obtained using the Diet 2 calculation. Use of the Diet 1 model age (3020-2760 cal BP) would place initial cemetery use prior to the midden, and there is nothing in the associated material culture or field observations to suggest that this was the case. Initially, it was hoped to use short-lived nut charcoals from the midden deposits to further constrain the Bayesian analysis of the burials. However, a late date for the Conus sp. ring from Burial 59 (Wk-37681: 2760-2650 cal BP), and the very last possible dates established from the Trapezoidal prior model (Table 4; $2680 \mathrm{cal}$ BP) indicate several interments may have occurred in the cemetery after the deposition of Layer 2 in the Midden Zone (see also unmodelled probability distributions in Figure 5). Our burial results also suggest that the cemetery may have been in use prior to midden build up, but slow collagen turn over (inbuilt age) could have resulted in a separation of a few decades from short-lived midden materials. Consequently, we feel that statistically constraining the burial dates using information from the associated midden may be unrealistic. It should be noted that the flatness of calibration curve at c. 2650-2450 cal BP isn't a major concern to this interpretation since the cemetery age predates this.

Burial 3, possibly affected by terrestrial $\mathrm{C}_{4}$ protein, has a calibrated age range (2830-2570 cal BP) that extends into the post-Lapita midden period (Table 2 and Figure 5). $\mathrm{C}_{4}$ foods have $\delta^{13} \mathrm{C}$ values that appear marine in origin; it is therefore possible that the per-cent marine correction we have applied is too large. Interestingly Burial 3 is removed slightly from the main cemetery area 
(Figure 2). Both Burial 3 and Burial 18 had been identified as having a $\mathrm{C}_{4}$ protein component to their diets, but Burial 18 does not appear to have been affected (2920-2730 cal BP). It is possible

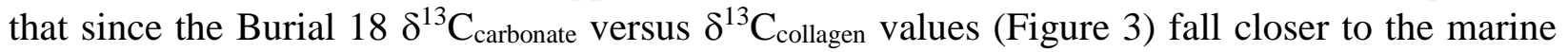
and $\mathrm{C}_{3}$ protein regression lines, the influence of $\mathrm{C}_{4}$ foods on the radiocarbon age is less. Our results also indicate that two of the individuals previously identified as foreign (burials 10e and 18), and almost certainly also Burial 3, are contemporary with the other burials, confirming continued contact with external regions throughout the duration of cemetery use.

Calibrated ages for two burials (burials 3 and 57) fall at the extreme age range. Only Burial 57 had a low individual agreement index $(A=43.2)$ in the Diet 2 model (Table 4, column 2), though the overall agreement for the model as outlined above is acceptable $\left(A_{\text {model }}=192.9\right)$. Although Burial 3 was not identified as an outlier, concerns about the affect of $\mathrm{C}_{4}$ protein, as outlined above, raise the possibility that this sample gives an unmodelled calibrated age range that is too young. Removing both Burial 3 and Burial 57 from the model, however, resulted in only a small shift of the start and end midpoint dates by around 10 years, to 2930-2860 cal BP and 2780-2720 cal BP respectively. This minimal change is to be expected because of the large number of dates involved in the analysis that force the model to an average value.

\section{DISCUSSION}

Orthodox chronologies place first Lapita settlement in the Reef/Santa Cruz Group, Vanuatu and New Caledonia c. 3200-3000 cal BP (Bedford et al. 2006; Sand 2010). The results presented here for Teouma suggest revision of this date to c. 3000 cal BP at the earliest for first colonization, which is much closer to the age of first colonization of Fiji. The earliest secure date for Fiji is from Matanamuani (Naigani Island) dating to c. 3010-2870 cal BP (Irwin et al. 2011; Nunn and Petchey 2013), while a slightly later date of 2850-2830 cal BP - refined by U/Th dates on coral abraders from the site of Nukuleka - is accepted for Tonga (Burley 2012; Burley et al. 2012). Lastly, Mulifanua in Samoa has a date of 2880-2750 cal BP (Petchey 2001; Reith and Hunt 2008). The new human bone dates for Teouma (2940-2880 cal BP), combined with the diverse regional affinities as indicated by isotopes (Bentley et al. 2007; Lees 2010) and material culture (Dickinson et al. 2013; Reepmeyer et al. 2011) support a hypothesis that Vanuatu remained at the centre of a region-wide interaction sphere for several generations after initial settlement.

Broadly, our dietary evaluation differs little from previous studies of Teouma diet which describe a predominantly "local" population that consumed a diet based on a broad-spectrum hunting and gathering subsistence with some agriculture, and with a preference for reef and inshore marine foraging environments (higher trophic level reef fish) (Kinaston 2010:129-131; Kinaston et al. 2014:13-14; Valentin et al. 2010b). There also seems to have been a small number of "immigrants" who ate a more terrestrial diet early in life (Bentley et al. 2007). Valentin et al. (2010a:1826) tentatively identified food proportions that suggested greater than $50 \%$ of the total protein consumed came from terrestrial sources. Our results suggest a higher $\%$ of marine protein was incorporated into the bone protein (between $51 \%$ and $79 \%$ [Burial $3=89 \%$ ]), but because of protein routing it is likely that the actual percentage of marine foods in the diet was less than this. Our results have also highlighted that $\mathrm{C}_{4}$ foods were a part of the diet, albeit small, for the majority of the individuals studied, though a higher amount of $\mathrm{C}_{4}$ protein intake is possible in rare cases. This may cause some additional dating uncertainty and is a recognised problem when dealing with Pacific island populations (Petchey and Green 2005). Ideally, the methodology we have used to identify $\mathrm{C}_{4}$ foods requires further research using Pacific examples. Our results do not support a subsistence that was reliant on pig, assuming the pigs ate only a small amount of marine foods, 
because this would result in a more terrestrial ${ }^{14} \mathrm{C}$ calibration (cf., Diet 1) for most burials given the pig isotopic values indicated in Figure 3, though a higher per-cent marine diet for pigs is possible. This would have made the burial ages older than the associated midden (dated to c. 29602660 cal BP), which is not consistent with the archaeological evidence

One shortfall of all dietary analyses at present is the inability to identify freshwater foods (Hedges and Reynard, 2007:1244). Isotope values for animals that feed on freshwater organisms are complex. Although they are typically depleted in ${ }^{13} \mathrm{C}$ and enriched in ${ }^{15} \mathrm{~N}$ values compared to animals in dry-land terrestrial systems (Privat et al., 2007; Richards et al., 2001), this is not always the case (Cook et al. 2001; Olsen et al. 2010) depending on local conditions. These distinctions are further masked by the complexity of the Pacific isotopic range. The elevated $\delta^{15} \mathrm{~N}$ results for a few individuals (Table 1) may be an indication of freshwater foods, though higher trophic level pelagic fish are also a possibility. Current theories on local economy suggest that while reef fish are a common feature in many archaeological sites in Vanuatu, pelagic or open-ocean species form only a small proportion of the midden remains (see Bedford 2003, 2006). Similarly, although a small stream ran adjacent to the northern edge of the Teouma site, no freshwater species have been identified in faunal assemblages of Lapita age from Vanuatu (Valentin et al. 2010b:1826). Given the limestone backdrop to the Teouma Bay, and Efate as a whole (Bedford et al. 2009:219), there is the potential for hardwater effects that could make both shell and human bone dates appear older than they really are. Given the concordance between the burial remains and the associated midden deposits, we think that any such impact will, however, be relatively small.

\section{CONCLUSIONS}

Radiocarbon dating of 36 Lapita-age burials and 5 associated Conus sp. artefacts from Teouma, Vanuatu, suggests the cemetery was in regular use by c. 2940-2880 cal BP and that initial use may have been as early as 2970 cal BP. Moreover, the last burials were interred around 2770-2710 cal $\mathrm{BP}$, possibly ending as late as $2680 \mathrm{cal} \mathrm{BP}$. This result is in agreement with radiocarbon dates obtained from the associated Area 2 and $2 \mathrm{~B}$ midden deposits at the site. Evidence of possible earlier use of the cemetery is indicated by the unmodelled calibrated age for Burial 57 (3110-2930 cal BP), but this cannot be independently substantiated from other radiocarbon dates or context at the present time, and it is possible that the older age reflects uncertainties with dietary ${ }^{14} \mathrm{C}$ offsets, slow collagen turnover, or statistical uncertainties. Similarly, the youngest burial dates may be the result of additional dating uncertainties associated with attributing a per-cent marine contribution to the bone protein via diet. This is almost certainly the case with Burial 3 where a diet that included $\mathrm{C}_{4}$ protein resulted in a $\delta^{13} \mathrm{C}$ value indicative of a higher per-cent marine diet than is actually the case. Our results also indicate that individuals previously identified as foreign to Teouma (burials $3,10 \mathrm{e}$ and 18) are contemporary with the other burials, demonstrating continued contact with external regions throughout the duration of cemetery use. The results contribute to a revisionist trend in the dating of the Lapita culture in Remote Oceania, which suggests an initial settlement date for the region beginning around $3000 \mathrm{BP}$. A possible implication of such an age might be that the Lapita sequence in the Bismarck Archipelago "homeland" did not in fact begin much before then, or its pottery would be expected to show greater stylistic difference from that of sites such as Teouma. A detailed reconsideration and re-dating of key Bismarck Lapita sites is now clearly required to address this question.

\section{ACKNOWLEDGEMENTS}


The excavations at Teouma were carried out over six field seasons (2004-2010) and were a joint initiative of the Vanuatu National Museum and The Australian National University (ANU), directed by Matthew Spriggs and Stuart Bedford and Ralph Regenvanu and Marcelin Abong, former and current Directors of the Vanuatu Cultural Centre. We acknowledge the support and assistance the Vanuatu Cultural Centre field worker for the area Silas Alben, and the traditional landowners and community of Eratap Village. The leaseholder Robert Monvoisin and family provided similar support and assistance. This study was funded by the Pacific Biological Foundation, Department of Archaeology and Natural History and School of Archaeology and Anthropology of ANU, Snowy Mountains Engineering Corporation Foundation, Mr. Brian Powell, National Geographic Scientific Research Grant 8038-06, and Australian Research Council Discovery Grants DP0556874 and DP0880789. Funding for this project came from Australian Research Council Discovery-Project Grants (DP0556874, DP0880789 and DP110101415) and the Waikato University Research Trust Contestable Fund. We would like to thank two anonymous reviewers for valuable comments.

\section{BIBLIOGRAPHY}

Allen, M.S., Craig, J.A., 2009. Dynamics of Polynesian subsistence: insights from archaeofauna and stable isotopes studies, Aitutaki, Southern Cook Islands Pacific Sciences 63:477-506.

Ambrose, S.H., 1993. Isotopic analysis of paleodiets: methodological and interpretive considerations. In: Sandford, M.K. (Ed.), Elemental and Isotopic Analyses: Understanding Diet and Disease in Past Populations. Gordon and Breach Science Publishers, New York, pp. 59-130.

Ambrose, S.H., Norr, L., 1993. Experimental evidence for the relationship of the carbon isotope ratios of whole diet and dietary protein to those of bone collagen and carbonate. In: Malbert, J.B., Grupe, G. (Eds.), Prehistoric Human Bone: Archaeology at the Molecular Level. Springer-Verlag, Berlin, pp. 1-38.

Beavan Athfield, N., Green, R.C., Craig, J., McFadgen, B., Bickler, S., 2008. Influence of marine sources on ${ }^{14} \mathrm{C}$ ages: isotopic data from Watom Island, Papua New Guinea inhumations and pig teeth in light of new dietary. Journal of the Royal Society of New Zealand 38 (1):1-23.

Bedford, S., 2003. The timing and nature of Lapita colonisation in Vanuatu: the haze begins to clear. In: Sand, C. (Ed.), Pacific Archaeology: Assessments and prospects. Proceedings of the conference for the 50th Anniversary of the first Lapita excavation. Koné-Nouméa, 2002. Les Cahiers de l'Archéologie en Nouvelle-Calédonie 15. Département Archéologie de la Direction des Affaires Culturelles et Coutumières, Nouméa, pp. 147-158.

Bedford, S., 2006. Pieces of the Vanuatu Puzzle: Archaeology of the North,South and Centre. Pandanus Press, Australian National University ,Terra Australis 23, Canberra. http://epress.anu.edu.au/ta23_citation.html.

Bedford, S., Spriggs, M., Regenvanu, R., 2006. The Teouma Lapita site and the early human settlement of the Pacific Islands. Antiquity 80(310):812-828. 
Bedford, S., Spriggs, M., Buckley, H. R., Valentin, F., Regenvanu, R., 2009. The Teouma Lapita site, South Efate, Vanuatu: a summary of three field seasons (2004-2006). In P. Sheppard, T. Thomas, and G.R. Summerhayes (Eds), Lapita: Ancestors and Descendants, 215-234. Auckland: New Zealand Archaeological Association Monograph 28.

Bedford, S., Spriggs, M., Buckley, H., Valentin, F., Regenvanu, R., Abong, M., 2010. A cemetery of first settlement: Teouma, South Efate, Vanuatu/ Un cimetière de premier peuplement: le site de Teouma, sud d'Efate, Vanuatu. In C. Sand and S. Bedford (Eds), Lapita: Oceanic Ancestors/ Lapita: Ancêtres Océaniens, 140-161. Paris: Musée de Quai Branly/Somogy.

Bentley, R.A., Buckley, H.R., Spriggs, M., Bedford, S., Ottley, C.J., Nowell, G.M., Macpherson, C.G., Pearson, D.G., 2007. Lapita migrants in the Pacific's oldest cemetery: isotopic analysis at Teouma, Vanuatu. American Antiquity, 72:645-656.

Brock F., C Bronk Ramsey, T Higham, 2007. Quality assurance of ultrafiltered bone dating. Radiocarbon 49(2):187-192.

Bronk-Ramsey, C., 1995. Radiocarbon calibration and analysis of stratigraphy: the OxCal program. Radiocarbon 37:425-430.

Bronk-Ramsey, C., Higham, T.F.G., Bowles, A., Hedges, R.E.M., 2004. Improvements to the pretreatment of bone at Oxford. Radiocarbon 46(1):155-163.

Bronk-Ramsey, C., 2013. OxCal Program v4.2, Radiocarbon Accelerator Unit. University of Oxford.

Burley, D.V., Weisler M.I., Zhao J-x,, 2012. High Precision U/Th Dating of First Polynesian Settlement. PLoS ONE 7(11): e48769. doi:10.1371/journal.pone.0048769.

Burley, D.V., 2012. Exploration as a strategic process in the Lapita settlement of Fiji: the implications of Vorovoro Island. Journal of Pacific Archaeology 3:22-34.

Clark, G., Petchey, F., Hawkins, S., Reepmeyer, C., Smith, I., Masse, W.B., 2013. Distribution and extirpation of pigs in Pacific Islands: A case study from Palau. Archaeology in Oceania; doi: $10.1002 / \operatorname{arco} .5012$

Clark, I., Fritz, P., 2000. Environmental Isotopes. In Hydrogeology. Department of Earth Sciences, University of Ottawa, Canada. Available http://www.science.uottawa.ca/chi/chl.htm. Accessed 22/2/2013.

Cook, G.T., Bonsall, C., Hedges, R.E.M., McSweeney, K., Boronean, V., Pettitt, P.B., 2001. A freshwater diet-derived ${ }^{14} \mathrm{C}$ reservoir effect at the Stone Age sites in the Iron Gates gorge. Radiocarbon 43(2):453-460.

DeNiro, M.J., 1985. Post-mortem preservation and alteration of in vivo bone collagen isotope ratios on relation to palaeodietary reconstruction. Nature 317(6032), 806-809. 
DeNiro, M.J., Epstein, S., 1978. Influence of diet on the distribution of carbon isotopes in animals. Geochimica et Cosmochimica Acta 42:495-506.

Dewar, G., Pfeiffer, S., 2010. Approaches to estimating marine protein in human collagen for radiocarbon date calibration. Radiocarbon 52(4):1611-1625.

Dickinson, W., Bedford, S. Spriggs, M., 2013, Petrography of Temper Sands in 112 Reconstructed Lapita Pottery Vessels from Teouma (Efate): Archaeological implications and relations to other Vanuatu tempers. Journal of Pacific Archaeology 4(2):1-20.

Field, J.S., Cochrane, E.E., Greenlee, D.M., 2009. Dietary change in Fijian prehistory: isotopic analyses of human and animal skeletal material. Journal of Archaeological Science 36:1547-1556.

Fischer, A., Olsen, J., Richards M., Heinemeier, J., Sveinbjrnsdttir, E., Bennike, P., 2007. Coastinland mobility and diet in the Danish Mesolithic and Neolithic: evidence from stable isotope values of humans and dogs. Journal of Archaeological Science 34:2125-2150.

Frémondeau, D., Cucchi, T., Casabianca, F., Ughetto-Monfrin, J., Horard-Herbin, M-P., Balasse, M., 2012. Seasonality of birth and diet of pigs from stable isotope analysis of tooth enamel $\left(\delta^{18} \mathrm{O}\right.$, $\left.\delta^{13} \mathrm{C}\right)$ : A modern reference data set from Corsica, France. Journal of Archaeological Science 39(7):2023-2035.

Hedges, R.E.M., Reynard, L.M., 2007. Nitrogen isotopes and the trophic level of humans in archaeology. Journal of Archaeological Science 34:1240-1251.

Hogg, A.G., Hua Q., Blackwell, P.G., Niu, M., Buck, C.E., Guilderson, T.P., Heaton, T.J., Palmer, J.G., Reimer, P.J., Reimer, R.W., Turney, C.S.M., Zimmerman, S.R.H., 2013. ShCal13 Southern Hemisphere calibration, 0-50,000 years cal BP. Radiocarbon 55(4):1889-1903.

Irwin, G., Worthy, T.H., Best, S., Hawkins, S., Carpenter, J., Matararaba, S., 2011. Further investigations at the Naigani Lapita site (VL 21/5), Fiji: excavation, radiocarbon dating and palaeofaunal extinction. Journal of Pacific Archaeology 2:66-78.

Jones, S., Quinn, R., 2009. Prehistoric Fijian diet and subsistence: integration of Faunal, Ethnographic and stable isotope evidence from the Lau Island group. Journal of Archaeological Science 36:2742-2754.

Kellner, C., Schoeninger, M.J., 2007. A simple carbon isotope model for reconstructing prehistoric human diet. American Journal of Physical Anthropology 133:1112-1127.

Kinaston, R.L., Buckley, H.R., Halcrow, S.E., Spriggs, M.J.T., Bedford, S., Neal, K, Gray A., 2009. Investigating foetal and perinatal mortality in prehistoric skeletal samples: a case study from a 3000-year-old Pacific Island cemetery site. Journal of Archaeological Science 36(12):2780-2787. 
Kinaston, R., 2010. Prehistoric Diet and Health in the Western Pacific Islands. PhD thesis, University of Otago, Dunedin, New Zealand.

Kinaston, R., Buckley, H., Gray, A., Shaw, B., Mandui, H., 2013a. Exploring subsistence and cultural complexes on the south coast of Papua New Guinea using palaeodietary analyses. Journal of Archaeological Science 40:904-913.

Kinaston, R.L., Walter, R.K. Jacomb, C., Brooks, E., Tayles, N., Halcrow, E.E., Stirling, C., Reid, M., Gray, A.R., Spinks, J., Shaw, B., Fyfe, R. Buckley, H.R., 2013b. The first New Zealanders: Patterns of diet and mobility revealed through isotope analysis. PLOS ONE 8(5):1-11.

Kinaston, R.L., Buckley, H.R., Valentin, F., Bedford, S., Spriggs, M., Herrscher, E., 2014. Lapita diet in Remote Oceania: new stable isotope evidence from the 3000-year-old Teouma site, Efate Island, Vanuatu PLOS ONE: DOI: 10.1371/journal.pone.0090376.

Lamb, A.L., Melikian, M., Ives, R., Evans, J., 2012. Multi-isotope analysis of the population of the lost medieval village of Auldhame, East Lothian, Scotland. Journal Analytical Atomic Spectrometry 27:765-777.

Leach, B.F., Quinn, C.J., Lyon, G.L., 1996. A stochastic approach to the reconstruction of prehistoric human diet in the Pacific region from bone isotope signatures. Tuhinga, Records of the Museum of New Zealand Te Papa Tongarewa 8:1-54.

Leach, B.F., Quinn, C.J., Lyon, G.L., Haystead, A., Myers, D.B., 2000. Evidence of prehistoric Lapita diet at Watom island, Papua New Guinea, using stable isotopes. New Zealand Journal of Archaeology 20 (1998):149-159.

Leach, B.F., Quinn, C., Morrison, J., Lyon, G., 2003. The use of multiple isotope signatures in reconstructing prehistoric human diet from archaeological bone from the Pacific and New Zealand. New Zealand Journal of Archaeology 23 (2001):31-98.

Lees, W., 2010. In situ strontium isotope analysis of human teeth from Teouma, Efate, Vanuatu for tracing Lapita colonisation. Unpublished Masters thesis, the Australian National University.

Lee, S., Bronk Ramsey, C., 2012. Development and application of the trapezoidal model for archaeological chronologies. Radiocarbon 54(1):107-122.

Lee-Thorp, J.A., Sponheimer, M., Luyt, J., 2007. Tracking changing environments using stable carbon isotopes in fossil tooth enamel: an example from the South African hominin sites. Journal of Human Evolution 53:595-601

Longin, R., 1971. New method of collagen extraction for radiocarbon dating. Nature 230:241-242.

McCormac, F.G., Hogg, A.G., Blackwell, P.G., Buck, C.E., Higham, T.F.G., Reimer, P.J., 2004. SHCal04 southern hemisphere calibration 0-11.0 cal kyr BP. Radiocarbon 46:1087-1092. 
Martin, P., Bruce, Burr, D.B., Sharkey, N.A., 1998. Skeletal Tissue Mechanism. Springer-Verlag, New York, pp. 137.

Nunn, P.D., Petchey, F., 2013. Bayesian re-evaluation of Lapita settlement in Fiji: radiocarbon analysis of the Lapita settlement at Bourewa and nearby sites on the Rove Peninsula, Viti Levu Island. Journal of Pacific Archaeology 4(2):21-34.

Olsen, J., Heinemeier, J., Lübke, H., Lüth, F., Terberger, T., 2010. Dietary habits and freshwater reservoir effects in bones from a Neolithic NE German cemetery. Radiocarbon 52(2):635-644.

Petchey, F., 2001. Radiocarbon Determinations from the Mulifanua Lapita site, Upolu, Western Samoa. Radiocarbon 43(1):63-68.

Petchey, F., Green, R., 2005. Use of three isotopes to calibrate human bone radiocarbon determinations from Kainapirina (SAC), Watom Island, Papua New Guinea. Radiocarbon 47(2):181-192.

Petchey, F., Anderson, A., Zondervan, A., Ulm, S., Hogg, A., 2008. New marine $\Delta$ R values for the South Pacific subtropical gyre region. Radiocarbon 50(3):373-397.

Petchey, F., Spriggs, M., Leach, F., Seed, M., Sand, C., Pietrusewsky, M., Anderson, K., 2011. Testing the human factor: Radiocarbon dating the first peoples of the South Pacific. Journal of Archaeological Science 38:29-44.

Petchey, F., Ulm, S., David, B., McNiven, I.J., Asmussen, B. Tomkins, H., Dolby, N., Aplin, K., Richards, T., Rowe, C., Leavesley, M., Mandui, H., 2013. High-resolution radiocarbon dating of marine materials in archaeological contexts: Radiocarbon marine reservoir variability between Anadara, Gafrarium, Batissa, Polymesoda and Echinoidea at Caution Bay, Southern Coastal Papua New Guinea. Archaeological and Anthropological Sciences 5(1):69-80.

Privat, K.L., O'Connell, T.C., Hedges, R.E.M., 2007. The distinction between freshwater and terrestrial-based diets: Methodological concerns and archaeological applications of sulphur stable isotope analysis. Journal of Archaeological Science 34:1197-1204.

Reepmeyer, C., Spriggs, M., Bedford, S., Ambrose, W., 2011. Provenance and technology of lithic artefacts from the Teouma Lapita site, Vanuatu. Asian Perspectives 49(1) [2010]:205-225.

Reimer, P.J., Bard, E., Bayliss, A., Beck, J.W., Blackwell, P.G., Bronk Ramsey, C., Buck, C.E., Cheng, H., Edwards, R.L., Friedrich, M., Grootes, P.M., Guilderson, T.P., Haflidason, H., Hajdas, I., Hatté, C., Heaton, T.J., Hoffmann, D.L., Hogg, A.G., Hughen, K.A., Kaiser, K.F., Kromer, B., Manning, S.W., Niu M., Reimer, R.W., Richards, D.A., Scott, E.M., Southon, J.R., Staff, R.A., Turney, C.S.M., van der Plicht, J., 2013. IntCal13 and Marine13 radiocarbon age calibration curves, 0-50 000 years cal BP. Radiocarbon 55 (4):1869-1887.

Reith, T.M., Hunt T.L., 2008. A radiocarbon chronology for Samoan prehistory. Journal of Archaeological Science 35(7):1901-1927. 
Reitsema, L.J., Crews, D.E. Polcyn, M., 2010. Preliminary evidence for medieval Polish diet from carbon and nitrogen stable isotopes. Journal of archaeological Science 37:1413-1423.

Richards, M.P., Hedges, R.E.M., 1999. A Neolithic revolution? New evidence of diet in the British Neolithic. Antiquity 73:891-897.

Richards, M.P., Hedges, R.E.M., Molleson, T.I., Vogel, J.C., 1998. Stable Isotope analysis reveals variations in human diet at the Poundbury Camp Cemetery site. Journal of Archaeological Science 25:1247-1252.

Richards, M.P., Fuller, B.T., Hedges, R.E.M., 2001. Sulphur isotopic variation in ancient bone collagen from Europe: implications for human paleodiet, residence mobility, and modern pollutant studies. Earth and Planetary Science Letters 191:185-90.

Richards, M.P., West, E., Rolett, B., Dobney, E., 2009. Isotope analysis of human and animal diets from the Hanamiai archaeological site (French Polynesia). Archaeology in Oceania 44:29-37.

Sand, C., 2010. Lapita Calédonien: Archéologie d'un Premier Peuplement Insulaire Océanien. Travaux et Documents Océanistes 2. pp. 295. Société des Océanistes, Paris.

Schoeninger, M., DeNiro, M., 1984. Nitrogen and carbon isotopic composition of bone collagen from marine and terrestrial animals. Geochimica et Cosmochimica Acta 48:625-639.

Schoeninger, M., DeNiro, M., Tauber, H., 1983. Stable nitrogen isotope ratios of bone collagen reflect marine and terrestrial components of prehistoric human diet. Science 220:1381-1383.

Schulting, R.J., Richards, M.P., 2002. Finding the coastal Mesolithic in southwest Britain: AMS dates and stable isotope results on human remains from Caldey Island, South Wales. Antiquity 76:1011-1025.

Scott, R., Buckley, H.R., Spriggs, M., Valentin, F., Bedford, S., 2010. Identification of the first reported Lapita cremation in the Pacific islands using archaeological, forensic and contemporary burning evidence. Journal of Archaeological Science 37:901-909.

Spriggs, M., Bedford, S., 2013. Is there an incised Lapita phase after dentate-stamped pottery ends? Data from Teouma, Efate Island, Vanuatu. In G. Summerhayes and H. Buckley (Eds), Lapita Directions: Documenting the Past 50,000 Years, 148-156. University of Otago Studies in Archaeology 25. Dunedin: Department of Anthropology and Archaeology, University of Otago.

Tieszen, L.L., Fagre, T., 1993. Effect of diet quality and composition on the isotopic composition of respiratory $\mathrm{CO} 2$, bone collagen, bioapatite, and soft tissues. In: Lambert, J.B., Grupe, G. (Eds.), Molecular Archaeology of Prehistoric Human Bone. Springer, Berlin, pp. 121-155.

UCI AMS. Chemical Pretreatment for bone: Ultrafiltration method. KCCAMS Internal Technical Report Sept 7, 2006. 
Valentin, F., Bocherens, H., Gratuze, B., Sand, C., 2006. Dietary patterns during the Late prehistoric/historic period in Cikobia Island (Fiji): insights from stable isotopes and dental pathologies. Journal of Archaeological Science 33:1396-1410.

Valentin, F., Bedford, S., Buckley, H., Spriggs, M., 2010a. Lapita burial practices: Evidence for complex body and bone treatment at the Teouma cemetery, Vanuatu, southwest Pacific. Journal of Island and Coastal Archaeology 5(2):212-235.

Valentin, F., Buckley, H., Herrscher, E., Kinaston, R., Bedford, S., Spriggs, M., Neal, K., $2010 b$. Lapita subsistence strategies and food consumption patterns in the community of Teouma (Efate, Vanuatu). Journal of Archaeological Science 37:1820-1829.

Valentin, F., Herrscher, E., Petchey, F., Addison, D.J., 2011. An analysis of the last 1000 years human diet on Tutuila (American Samoa) using carbon and nitrogen stable isotope data. American Antiquity 76(3):473-486.

Van der Merwe, N.J., Vogel, J.C., 1978. ${ }^{13} \mathrm{C}$ content of human collagen as a measure of prehistoric diet in Woodland North America. Nature 276:815-816.

van Klinken, G.J., 1999. Bone collagen quality indicators for palaeodietary and radiocarbon measurement. Journal of Archaeological Science 26:687-695.

van Klinken, G.J., Richards, M.P., Hedges, R.E.M., 2000. An overview of causes for stable isotopic variations in past European human populations: environmental ecophysiological and cultural effects. In: Ambrose, S.H., Katzenberg, M.A. (Eds.), Biogeochimical Approaches to Paleodietary Analysis. Advances in Archaeological and Museum Science. Kluwer Academic/Plenum Publishers, New York, pp. 39-58. 

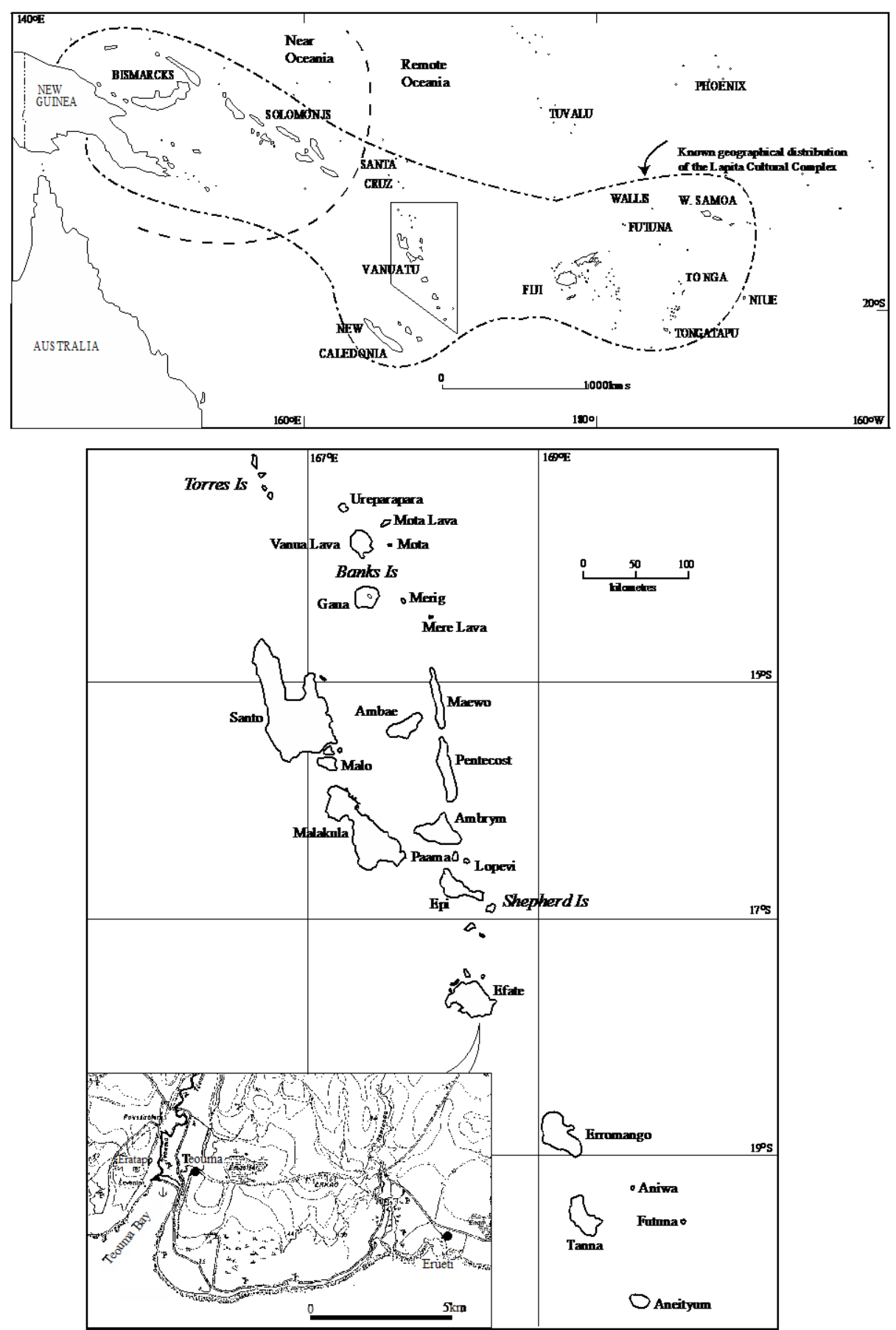

Figure 1. Map of Remote Oceania showing location of Vanuatu. Insert: The Teouma archaeological site. 


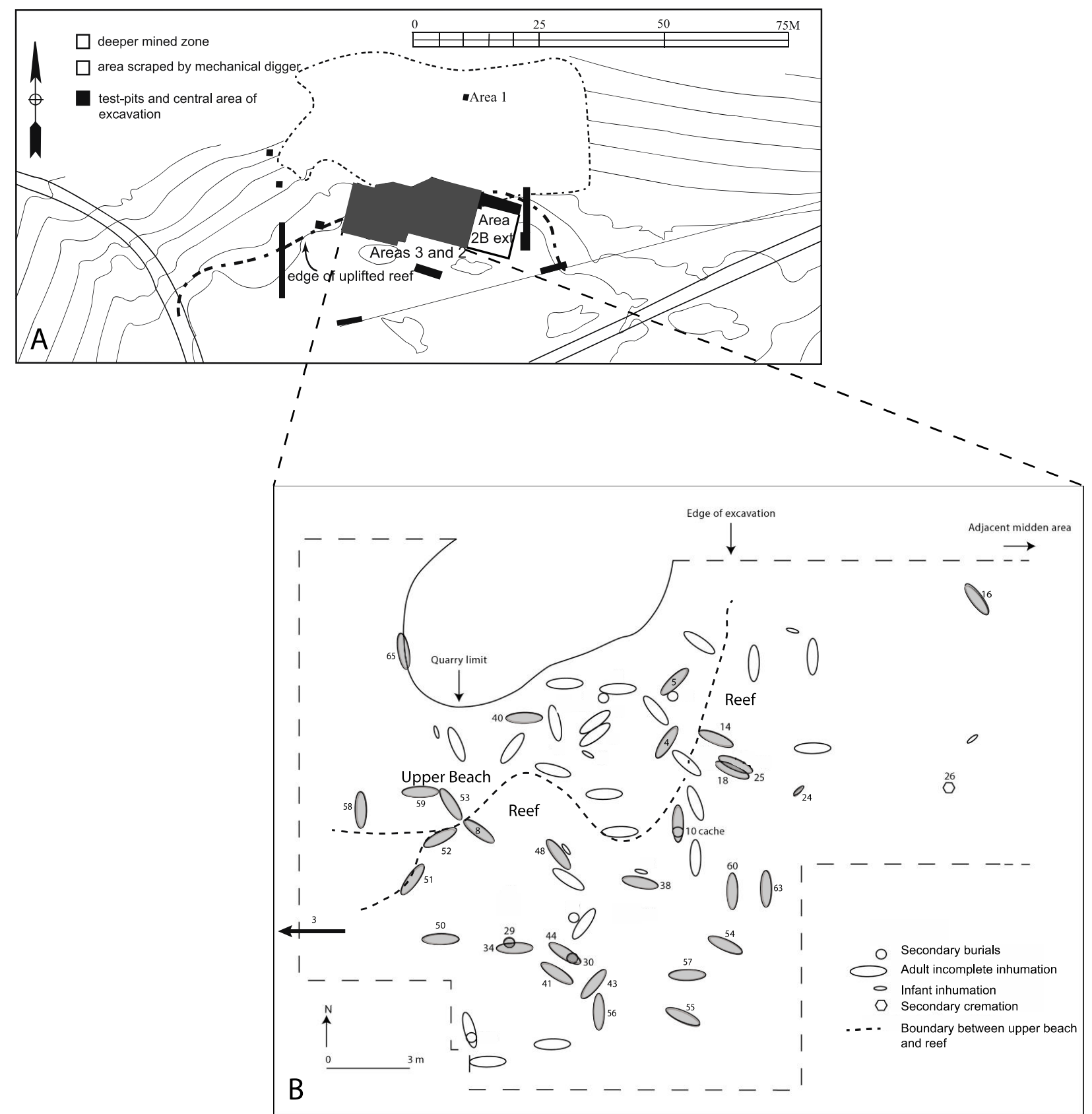

Figure 2: A. Teouma excavations showing location of the Cemetery Zone in relation to Area 2B extension (Midden Zone). B. Plan of the Teouma cemetery showing location of dated burials highlighted in grey (Note: Burial 3 is not located in the main burial area)(adapted from plan drawn by Florence Alliése and Frédérique Valentin). 


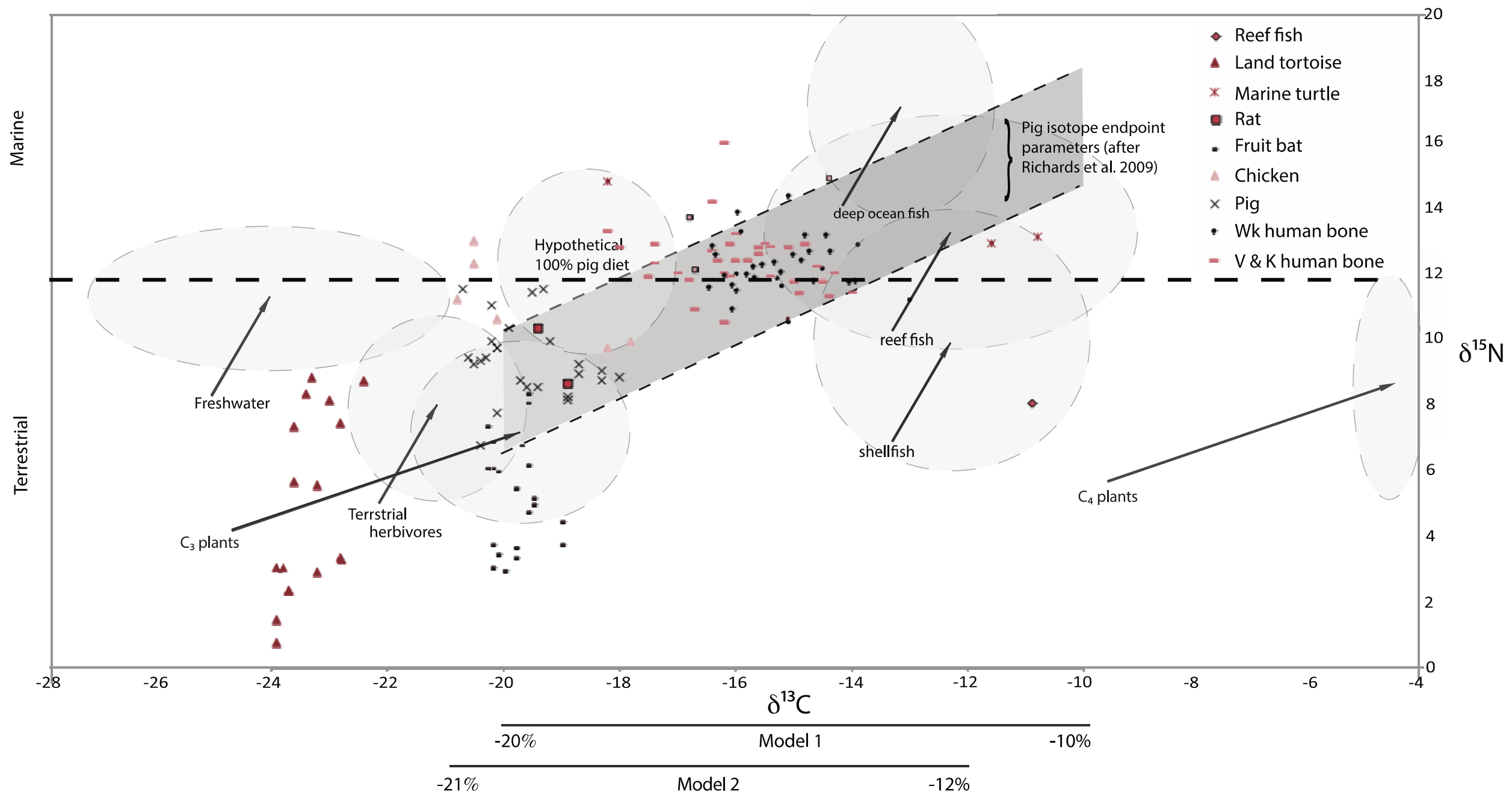


Figure 3: Teouma bone collagen $\delta^{13} \mathrm{C}$ and $\delta^{15} \mathrm{~N}$ values overlain by Pacific island dietary values \pm 1 SD corrected for a diet to tissue shift of $+1 \%$ for $\delta^{13} \mathrm{C}$ from protein sources and $+5 \%$ for $\delta^{13} \mathrm{C}$ from plant food and $+3.5 \%$ or $\delta^{15} \mathrm{~N}$ ) shown as grey ellipses. All modern values are adjusted for the Suess effect and faunal bone collagen $\delta^{13} \mathrm{C}$ values are corrected for the difference between bone collagen and flesh by subtracting $3.7 \%$ for fish bone and $1.5 \%$ for other animal bone ${ }^{10}$ Only bone isotope values that conform to the quality assurance protocols outlined in the text are given. The horizontal dashed line is the approximate division in $\delta^{15} \mathrm{~N}$ between terrestrial and marine diets (after Richards et al. 1998:1248). 


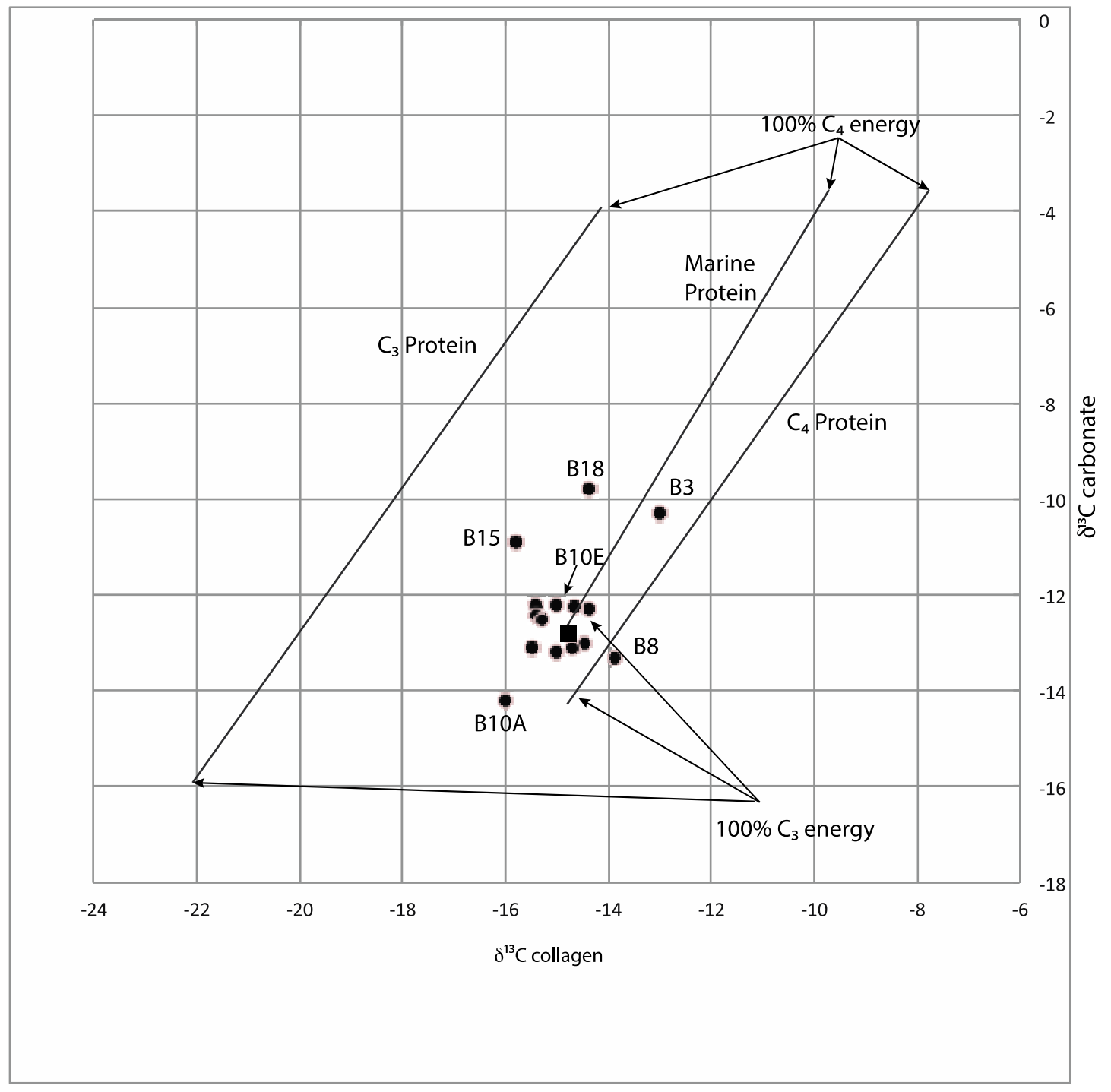


Figure 4: $\delta^{13} \mathrm{C}_{\text {carbonate }}$ plotted against $\delta^{13} \mathrm{C}_{\text {collagen }}$ using Kellner and Schoeninger's (2007) threeregression line model whereby each line corresponds to a protein source $\left(\mathrm{C}_{3}, \mathrm{C}_{4}\right.$ or marine) and an individual's placement between the endpoints of each protein line indicates energy source $\left(\mathrm{C}_{3}, \mathrm{C}_{4}\right.$, or mixed). Dark circles correspond to bone collagen values collected in this study relative to tooth carbonate values (see Table 1) from Bentley et al. (2007:653, figure 4). Light grey circles (B3, B10e and B18) are values from burials identified by Bentley et al. (2007) as foreigners on the basis of ${ }^{87} \mathrm{Sr} /{ }^{86} \mathrm{Sr}$ and $\delta^{18} \mathrm{O}$. 


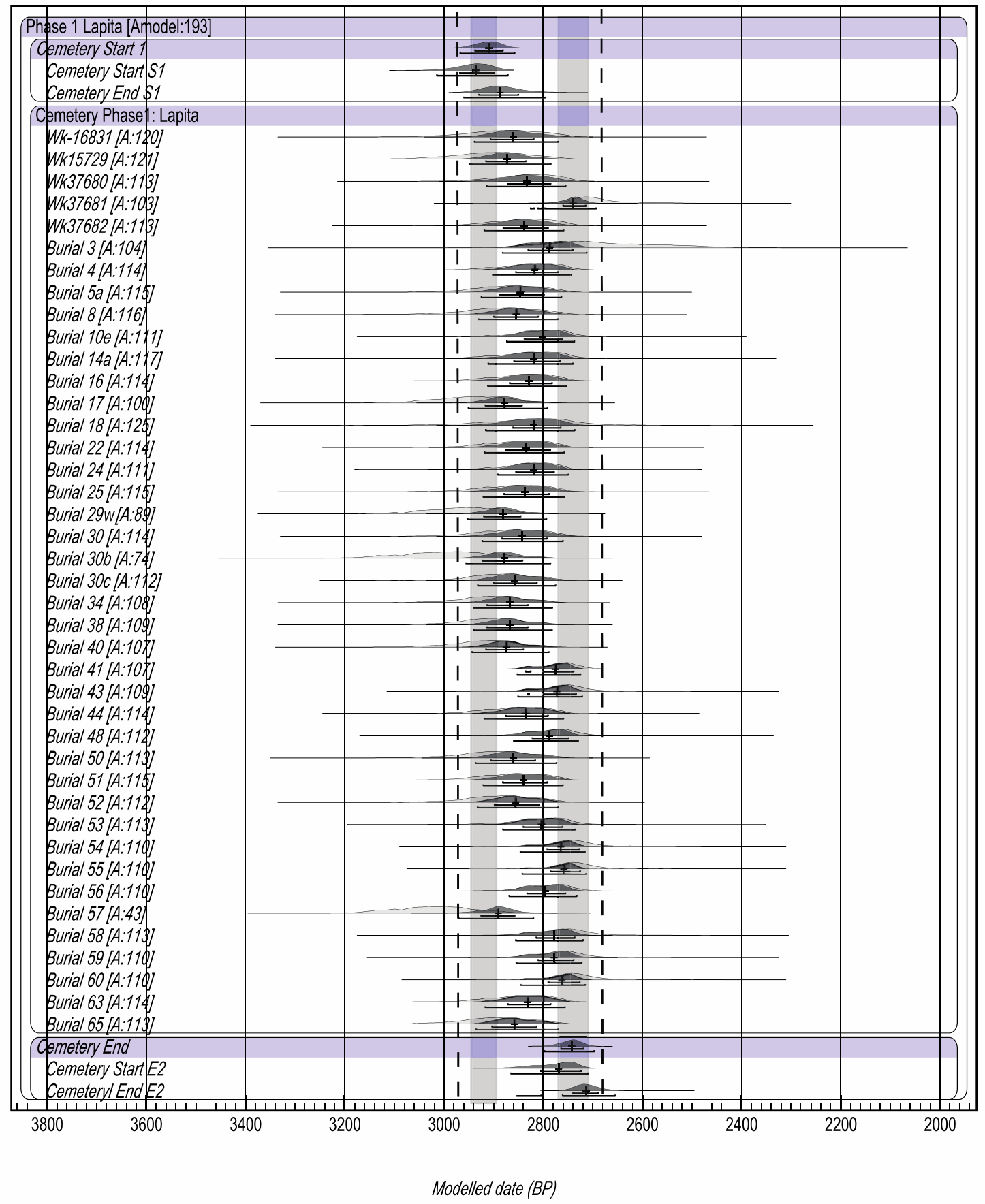

Figure 5: Calibrated radiocarbon ages for burials from the Teouma cemetery, Vanuatu using Diet $2\left(\delta^{13} \mathrm{C}\right.$ terrestrial/marine endpoints of $\left.-21 /-12 \%\right)$ dietary corrections. The outline date distributions show the unmodelled calibrated ages for each individual sample. The solid black distributions show the calculated ranges when applying the Bayesian model outlined in the text (quoted agreement indices [A] vary slightly by run). Vertical grey bars mark the start and end dates for the model cemetery chronology. Dashed lines represent the very earliest and very latest dates calculated using Trapezoidal priors following the methodology of Lee and Bronk Ramsey (2012). 

Table 1: Quality assurance and stable isotope data for Teouma burials.

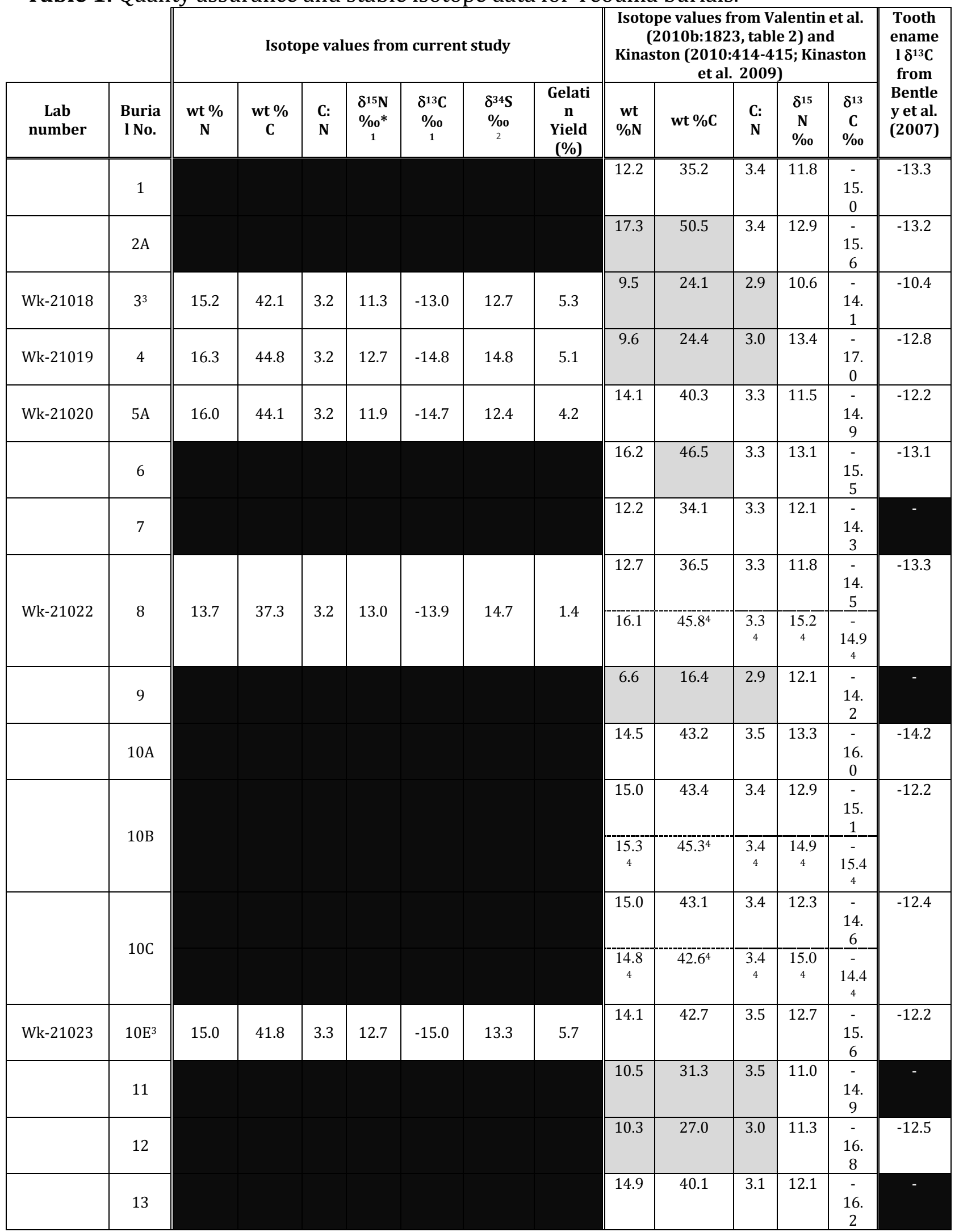




\begin{tabular}{|c|c|c|c|c|c|c|c|c|c|c|c|c|c|c|}
\hline \multirow{2}{*}{ Wk-21024 } & \multirow{2}{*}{14} & \multirow{2}{*}{15.0} & \multirow{2}{*}{41.5} & \multirow{2}{*}{3.2} & \multirow{2}{*}{13.3} & \multirow{2}{*}{-14.5} & \multirow{2}{*}{13.8} & \multirow{2}{*}{2.0} & 7.9 & 20.5 & 3.0 & 12.8 & $\begin{array}{c}- \\
16 . \\
7\end{array}$ & \multirow[t]{2}{*}{-13.0} \\
\hline & & & & & & & & & $\begin{array}{c}16.1 \\
4\end{array}$ & $46.7^{4}$ & $\begin{array}{c}3.4 \\
4\end{array}$ & $\begin{array}{c}13.8 \\
4\end{array}$ & $\begin{array}{c}- \\
16.4 \\
4\end{array}$ & \\
\hline & $15^{3}$ & & & & & & & & 14.7 & 43.2 & 3.4 & 12.5 & $\begin{array}{c}- \\
15 . \\
8\end{array}$ & -10.9 \\
\hline Wk-21025 & 16 & 15.4 & 42.8 & 3.3 & 11.9 & -15.3 & 14.3 & 2.3 & 14.0 & 41.7 & 3.5 & 10.6 & $\begin{array}{c}- \\
16 . \\
2\end{array}$ & -12.5 \\
\hline Wk-21026 & 17 & 16.3 & 44.9 & 3.2 & 12.7 & -14.7 & 15.0 & 2.4 & $\begin{array}{c}17.0 \\
4\end{array}$ & $48.7^{4}$ & $\begin{array}{c}3.3 \\
4\end{array}$ & $\begin{array}{c}15.5 \\
4\end{array}$ & $\begin{array}{c}- \\
13 . \\
74\end{array}$ & -13.1 \\
\hline \multirow[t]{5}{*}{ Wk-21027 } & $18^{3}$ & 13.5 & 37.7 & 3.3 & 12.8 & -14.4 & 14.4 & 3.0 & 13.1 & 40.1 & 3.6 & 11.5 & $\begin{array}{c}- \\
15 . \\
2\end{array}$ & -9.8 \\
\hline & \multirow{2}{*}{19} & & & & & & & & 14.7 & 41.9 & 3.3 & 12.0 & $\begin{array}{c}- \\
16 . \\
1\end{array}$ & \\
\hline & & & & & & & & & $\begin{array}{c}18.4 \\
4\end{array}$ & $51.8^{4}$ & $\begin{array}{c}3.3 \\
4\end{array}$ & $\begin{array}{c}11.8 \\
4\end{array}$ & $\begin{array}{c}- \\
17.2 \\
4\end{array}$ & \\
\hline & 20 & & & & & & & & 13.1 & 39.8 & 3.5 & 16.1 & $\begin{array}{c}- \\
16 . \\
2\end{array}$ & \\
\hline & 21 & & & & & & & & 14.4 & 42.5 & 3.5 & 12.5 & $\begin{array}{c}- \\
16 . \\
3\end{array}$ & \\
\hline \multirow[t]{2}{*}{ Wk-21028 } & 22 & 15.3 & 42.9 & 3.3 & 11.7 & -16.5 & 14.0 & 0.4 & & & & & 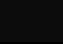 & \\
\hline & 23 & & & & & & & & 3.6 & 9.2 & 3.0 & 13.1 & $\begin{array}{c}- \\
15 . \\
0\end{array}$ & \\
\hline Wk-22655 & 24 & 15.2 & 43.1 & 3.3 & 11.6 & -16.0 & $\begin{array}{c}8.4 / 10 . \\
0\end{array}$ & 3.7 & 15.6 & 41.4 & 3.1 & 12.4 & $\begin{array}{c}- \\
17 . \\
4\end{array}$ & \\
\hline \multirow[t]{4}{*}{ Wk-21029 } & 25 & 16.0 & 44.8 & 3.3 & 14.0 & -16.0 & 15.4 & 1.8 & 12.1 & 35.4 & 3.4 & 14.3 & $\begin{array}{c}- \\
16 . \\
4\end{array}$ & \\
\hline & 27 & & & & & & & & 9.1 & 23.6 & 3.0 & 11.0 & $\begin{array}{c}- \\
18 . \\
6\end{array}$ & \\
\hline & \multirow{2}{*}{$29 \mathrm{E}$} & & & & & & & & 14.8 & 46.2 & 3.6 & 11.7 & $\begin{array}{c}- \\
16 . \\
9\end{array}$ & \\
\hline & & & & & & & & & $\begin{array}{c}15.4 \\
4\end{array}$ & $43.8^{4}$ & $\begin{array}{c}3.3 \\
4\end{array}$ & $\begin{array}{c}13.8 \\
4\end{array}$ & $\begin{array}{c}- \\
16.8 \\
4\end{array}$ & \\
\hline \multirow[t]{2}{*}{ Wk-22656 } & $29 \mathrm{~W}$ & 14.5 & 43.0 & 3.5 & 12.5 & -16.1 & - & 0.4 & $\begin{array}{c}16.3 \\
4\end{array}$ & $46.4^{4}$ & $\begin{array}{c}3.3 \\
4\end{array}$ & $\begin{array}{c}11.6 \\
4\end{array}$ & $\begin{array}{c}- \\
16 . \\
5^{4} \\
\end{array}$ & \\
\hline & $\begin{array}{c}30 \\
\text { (baby } \\
\text { ) }\end{array}$ & & & & & & & & 15.3 & 41.3 & 3.1 & 12.8 & $\begin{array}{c}- \\
16 . \\
4\end{array}$ & \\
\hline Wk-22657 & $30 \mathrm{~A}$ & 14.7 & 43.0 & 3.4 & 12.4 & -15.6 & - & 1.1 & 14.4 & 42.0 & 3.4 & 12.0 & $\begin{array}{c}- \\
15 . \\
4 \\
\end{array}$ & \\
\hline Wk-22658 & $30 \mathrm{~B}$ & 15.1 & 43.9 & 3.4 & 12.7 & -16.3 & 11.8 & 1.6 & 17.0 & 49.8 & 3.4 & 12.9 & $\begin{array}{c}- \\
15 . \\
8\end{array}$ & \\
\hline \multirow{2}{*}{ Wk-22659 } & \multirow{2}{*}{$30 \mathrm{C}$} & \multirow{2}{*}{15.4} & \multirow{2}{*}{44.3} & \multirow{2}{*}{3.4} & \multirow{2}{*}{12.0} & \multirow{2}{*}{-15.7} & \multirow{2}{*}{10.6} & \multirow{2}{*}{1.9} & 14.1 & 41.4 & 3.4 & 13.0 & $\begin{array}{c}- \\
14 . \\
8 \\
\end{array}$ & \\
\hline & & & & & & & & & $\begin{array}{c}15.5 \\
4\end{array}$ & $44.3^{4}$ & $\begin{array}{c}3.3 \\
4\end{array}$ & $\begin{array}{c}12.2 \\
4\end{array}$ & $\begin{array}{c}- \\
16.7 \\
4\end{array}$ & \\
\hline
\end{tabular}




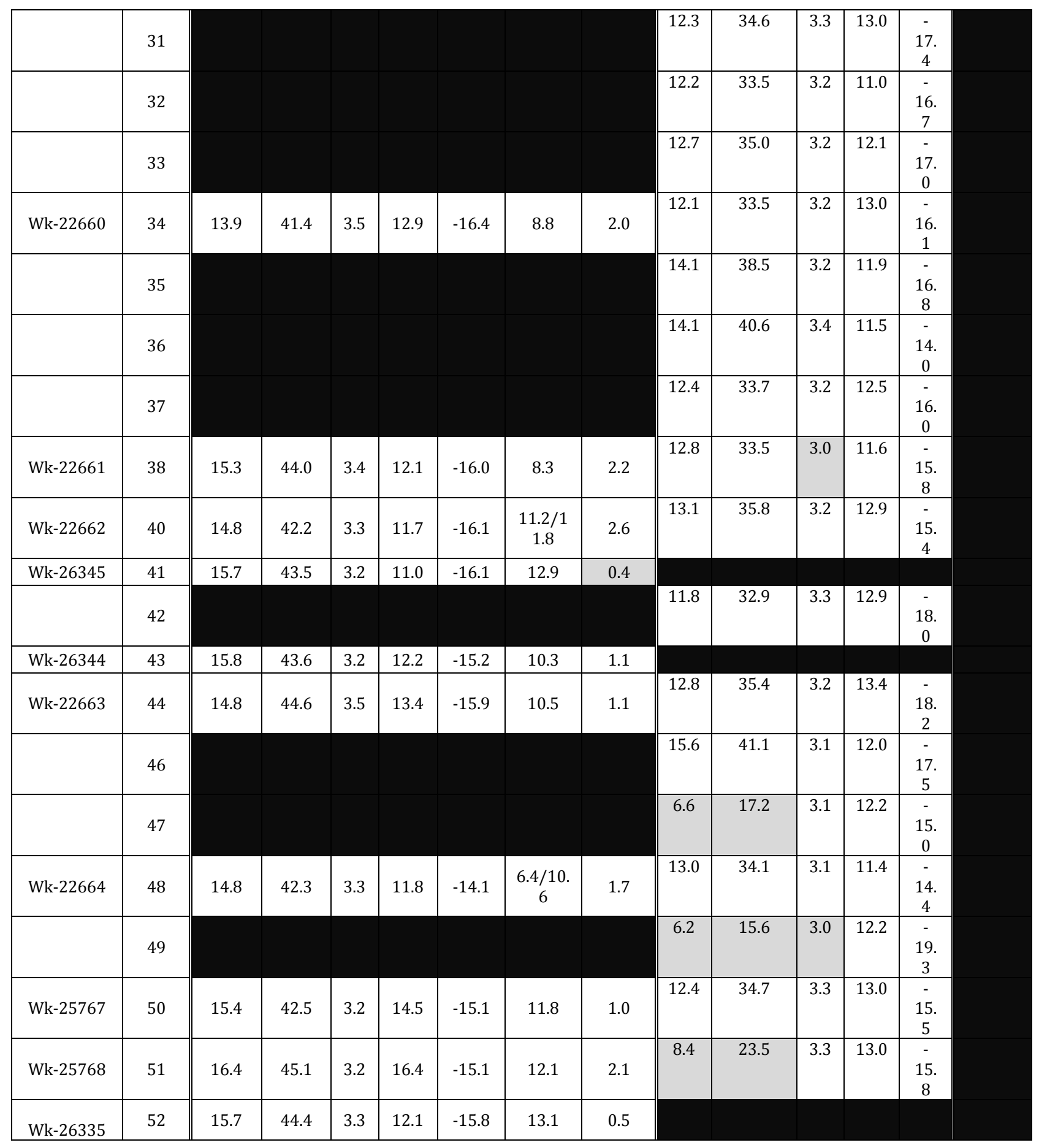




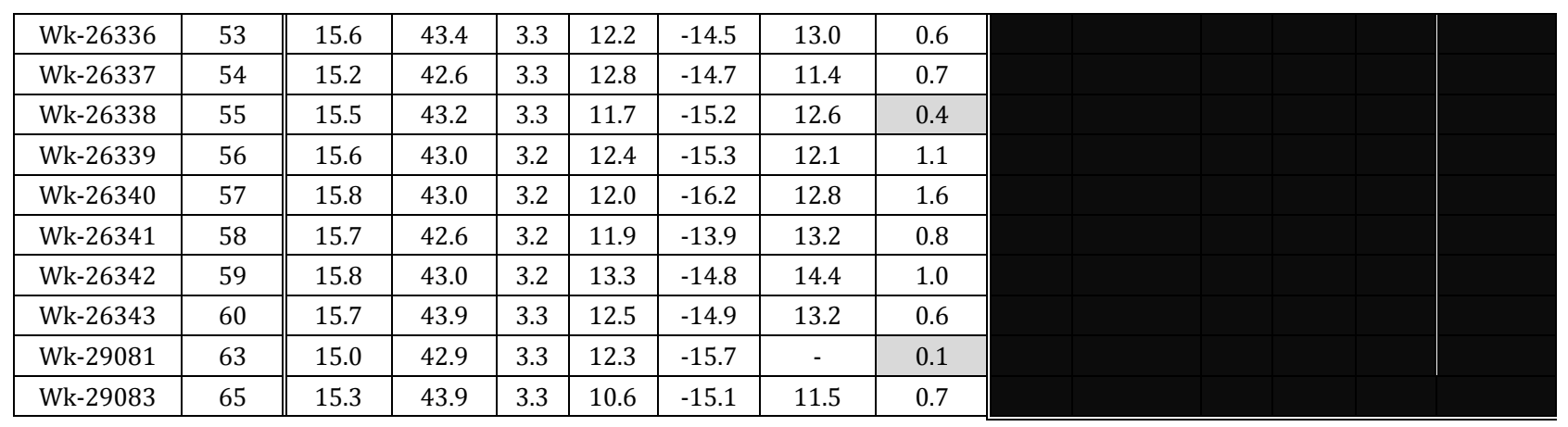

Footnotes:

${ }^{1} \delta^{13} \mathrm{C}$ measured relative to VPDB with precision of $\pm 0.1 \%$. $\delta^{15} \mathrm{~N}$ measured relative to AIR and with precision of $\pm 0.2 \%$.

${ }^{2} \delta^{34}$ S measured relative to IA-R061, IA-R042 and IA-R027 (Iso-Analytical) or IAEA-S-1, IAEA-S-2 and NBS123 (Isoprime) with precision of $\pm 0.3 \%$.

${ }^{3}$ Individuals identified as foreign by Bentley et al. 2007). Results highlighted in grey are those that failed the quality assurance (QA) and yield tests.

${ }^{4}$ Tooth stable isotope values from Kinaston (2010); 
Table 2: Conventional radiocarbon ages (CRA) and dietary values for human remains from Teouma.

\begin{tabular}{|c|c|c|c|c|c|c|c|c|}
\hline \multirow[b]{2}{*}{ Sample ID } & \multirow[b]{2}{*}{$\begin{array}{c}\text { Burial } \\
\text { No. }\end{array}$} & \multirow[b]{2}{*}{$\begin{array}{c}\% \\
\text { MarineC } \\
-20 /-10 \\
\text { (Diet 1) }\end{array}$} & \multirow[b]{2}{*}{$\begin{array}{c}\% \\
\text { MarineC } \\
-21 /-12 \\
\text { (Diet 2) }\end{array}$} & \multirow[b]{2}{*}{$\begin{array}{l}\text { CRA } \\
\text { (bp) }\end{array}$} & \multirow[b]{2}{*}{$\begin{array}{c}\delta^{13} \mathrm{C} \\
( \pm 0.2) \\
\text { IRMS } \\
\text { value }\end{array}$} & \multicolumn{3}{|c|}{$\begin{array}{c}\text { Dietary corrected (Diet } 2[-21 /-12]) \\
\text { calibrations }\end{array}$} \\
\hline & & & & & & $\begin{array}{l}\text { Unmodelled } \\
\text { Calibrated age } \\
\text { range cal BP } \\
(68.2 \% \text { prob. })\end{array}$ & $\begin{array}{c}\text { Unmodelled } \\
\text { Calibrated age } \\
\text { range } \\
\text { cal BP } \\
(95.4 \% \text { prob. }) \\
\end{array}$ & $\begin{array}{l}\text { Unmodelled } \\
\text { median } \\
\text { cal BP }\end{array}$ \\
\hline \multicolumn{9}{|c|}{ Lapita burials } \\
\hline $\begin{array}{c}\text { Wk- } \\
21018\end{array}$ & $3 \#$ & 70 & 89 & $\begin{array}{l}2932 \\
\pm 35\end{array}$ & -13.4 & $2830-2570$ & $2920-2420$ & 2700 \\
\hline $\begin{array}{c}\text { Wk- } \\
21019\end{array}$ & 4 & 52 & 69 & $\begin{array}{r}2969 \\
\pm 35 \\
\end{array}$ & -15.3 & $2870-2750$ & $2960-2720$ & 2820 \\
\hline $\begin{array}{c}\text { Wk- } \\
21020\end{array}$ & $5 \mathrm{~A}$ & 53 & 70 & $\begin{array}{l}3021 \\
\pm 26\end{array}$ & -15.2 & $2930-2780$ & $3000-2740$ & 2860 \\
\hline $\begin{array}{c}\text { Wk- } \\
21022\end{array}$ & 8 & 61 & 79 & $\begin{array}{c}3066 \\
\pm 23 \\
\end{array}$ & -14.1 & $2950-2800$ & $3030-2750$ & 2880 \\
\hline $\begin{array}{c}\text { Wk- } \\
21023\end{array}$ & $10 \mathrm{E} \#$ & 50 & 66 & $\begin{array}{l}2932 \\
\pm 26\end{array}$ & -15.7 & $2850-2740$ & $2920-2710$ & 2800 \\
\hline $\begin{array}{c}\text { Wk- } \\
21024\end{array}$ & 14 & 56 & 73 & $\begin{array}{l}2982 \\
\pm 47\end{array}$ & -15.2 & $2880-2740$ & $2980-2700$ & 2820 \\
\hline $\begin{array}{c}\text { Wk- } \\
21025\end{array}$ & 16 & 52 & 63 & $\begin{array}{r}2968 \\
\pm 30 \\
\end{array}$ & -15.5 & $2890-2760$ & $2970-2740$ & 2840 \\
\hline $\begin{array}{c}\text { Wk- } \\
21026\end{array}$ & 17 & 53 & 70 & $\begin{array}{l}3083 \\
\pm 26 \\
\end{array}$ & -15.1 & $3010-2850$ & $3110-2780$ & 2940 \\
\hline $\begin{array}{c}\text { Wk- } \\
21027\end{array}$ & $18 \#$ & 56 & 74 & $\begin{array}{l}2977 \\
\pm 23\end{array}$ & -15.0 & $2920-2730$ & $3050-2650$ & 2820 \\
\hline $\begin{array}{c}1 \text { Wk- } \\
21028\end{array}$ & 22 & 35 & 50 & $\begin{array}{l}2931 \\
\pm 35 \\
\end{array}$ & -16.4 & $2920-2770$ & $2970-2740$ & 2850 \\
\hline $\begin{array}{c}\text { Wk- } \\
22655\end{array}$ & 24 & 40 & 56 & $\begin{array}{l}2929 \\
\pm 2 \text { ? }\end{array}$ & -15.8 & $2860-2760$ & $2940-2740$ & 2820 \\
\hline $\begin{array}{c}\text { Wk- } \\
21029\end{array}$ & 25 & 40 & 56 & $\begin{array}{r}2958 \\
\pm 38 \\
\end{array}$ & -16.0 & $2920-2780$ & $3000-2740$ & 2850 \\
\hline $\begin{array}{c}\text { Wk- } \\
22656\end{array}$ & $29 W$ & 39 & 54 & $\begin{array}{c}3036 \\
\pm 32 \\
\end{array}$ & - & $3030-2870$ & $3140-2800$ & 2960 \\
\hline $\begin{array}{c}\text { Wk- } \\
22657\end{array}$ & $30 \mathrm{~A}$ & 45 & 61 & $\begin{array}{c}2983 \\
\pm 32 \\
\end{array}$ & -15.3 & $2920-2780$ & $2990-2740$ & 2860 \\
\hline $\begin{array}{c}\text { Wk- } \\
22658\end{array}$ & $30 \mathrm{~B}$ & 37 & 52 & $\begin{array}{l}3050 \\
\pm 49 \\
\end{array}$ & -16.1 & $3070-2880$ & $3170-2810$ & 2990 \\
\hline $\begin{array}{c}\text { Wk- } \\
22659\end{array}$ & $30 \mathrm{C}$ & 43 & 59 & $\begin{array}{r}2995 \\
\pm 2 ? \\
\end{array}$ & -15.4 & $2950-2810$ & $3010-2760$ & 2880 \\
\hline $\begin{array}{c}\text { Wk- } \\
22660\end{array}$ & 34 & 36 & 51 & $\begin{array}{l}2983 \\
\pm 24\end{array}$ & -16.2 & $2970-2830$ & $3040-2770$ & 2900 \\
\hline $\begin{array}{c}\text { Wk- } \\
22661\end{array}$ & 38 & 40 & 56 & $\begin{array}{r}3002 \\
\pm 23 \\
\end{array}$ & -15.8 & $2970-2830$ & $3040-2770$ & 2900 \\
\hline $\begin{array}{c}\text { Wk- } \\
22662\end{array}$ & 40 & 39 & 55 & $\begin{array}{r}3008 \\
\pm 2 \text { ? }\end{array}$ & -15.8 & $2980-2840$ & $3060-2780$ & 2910 \\
\hline $\begin{array}{c}\text { Wk- } \\
26345\end{array}$ & 41 & 39 & 55 & $\begin{array}{c}2848 \\
\pm 30 \\
\end{array}$ & -15.7 & $2810-2710$ & $2880-2670$ & 2760 \\
\hline $\begin{array}{c}\text { Wk- } \\
26344\end{array}$ & 43 & 48 & 64 & $\begin{array}{r}2875 \\
\pm 30\end{array}$ & -14.9 & $2810-2700$ & $2880-2610$ & 2760 \\
\hline $\begin{array}{c}\text { Wk- } \\
22663\end{array}$ & 44 & 41 & 57 & $\begin{array}{r}2960 \\
\pm 3 \text { ? } \\
\end{array}$ & -15.9 & $2920-2770$ & $2980-2740$ & 2850 \\
\hline $\begin{array}{c}\text { Wk- } \\
22664\end{array}$ & 48 & 60 & 77 & $\begin{array}{l}2954 \\
\pm 2 \text { 圆 }\end{array}$ & -14.1 & $2830-2730$ & $2920-2680$ & 2780 \\
\hline
\end{tabular}




\begin{tabular}{|c|c|c|c|c|c|c|c|c|}
\hline $\begin{array}{c}\text { Wk- } \\
25767\end{array}$ & 50 & 49 & 66 & $\begin{array}{c}3030 \\
\pm 30 \\
\end{array}$ & -15.1 & $2960-2810$ & $3040-2760$ & 2890 \\
\hline $\begin{array}{c}\text { Wk- } \\
25768 \\
\end{array}$ & 51 & 49 & 65 & $\begin{array}{r}2995 \\
\pm 30 \\
\end{array}$ & -15.1 & $2920-2780$ & $2990-2740$ & 2860 \\
\hline $\begin{array}{c}\text { Wk- } \\
26335\end{array}$ & 52 & 42 & 58 & $\begin{array}{c}2992 \\
\pm 30\end{array}$ & -15.7 & $2950-2810$ & $3020-2750$ & 2880 \\
\hline $\begin{array}{c}\text { Wk- } \\
26336\end{array}$ & 53 & 55 & 72 & $\begin{array}{c}2958 \\
\pm 30\end{array}$ & -14.4 & $2850-2740$ & $2930-2700$ & 2800 \\
\hline $\begin{array}{c}\text { Wk- } \\
26337\end{array}$ & 54 & 53 & 70 & $\begin{array}{c}2882 \\
\pm 30 \\
\end{array}$ & -14.6 & $2800-2690$ & $2870-2540$ & 2740 \\
\hline $\begin{array}{c}\text { Wk- } \\
26338\end{array}$ & 55 & 48 & 64 & $\begin{array}{l}2849 \\
\pm 30 \\
\end{array}$ & -15.1 & $2790-2680$ & $2850-2540$ & 2730 \\
\hline $\begin{array}{c}\text { Wk- } \\
26339\end{array}$ & 56 & 47 & 63 & $\begin{array}{r}2908 \\
\pm 30 \\
\end{array}$ & -15.3 & $2840-2740$ & $2920-2700$ & 2790 \\
\hline $\begin{array}{c}\text { Wk- } \\
26340\end{array}$ & 57 & 38 & 53 & $\begin{array}{c}3078 \\
\pm 30 \\
\end{array}$ & -16.3 & $3110-2930$ & $3170-2870$ & 3020 \\
\hline $\begin{array}{c}\text { Wk- } \\
26341\end{array}$ & 58 & 61 & 78 & $\begin{array}{r}2931 \\
\pm 34 \\
\end{array}$ & -14.1 & $2820-2710$ & $2890-2620$ & 2760 \\
\hline $\begin{array}{c}\text { Wk- } \\
26342\end{array}$ & 59 & 56 & 69 & $\begin{array}{c}2902 \\
\pm 30\end{array}$ & -14.7 & $2790-2680$ & $2860-2540$ & 2760 \\
\hline $\begin{array}{c}\text { Wk- } \\
26343\end{array}$ & 60 & 51 & 68 & $\begin{array}{c}2871 \\
\pm 30\end{array}$ & -14.6 & $2890-2760$ & $2970-2740$ & 2740 \\
\hline $\begin{array}{c}\text { Wk- } \\
29081\end{array}$ & 63 & 43 & 59 & $\begin{array}{r}2960 \\
\pm 32 \\
\end{array}$ & - & $2960-2810$ & $3040-2750$ & 2840 \\
\hline $\begin{array}{c}\text { Wk- } \\
29083 \\
\end{array}$ & 65 & 49 & 66 & $\begin{array}{r}3027 \\
\pm 31 \\
\end{array}$ & - & $2960-2810$ & $3040-2750$ & 2890 \\
\hline \multicolumn{9}{|c|}{ Conus sp. shell rings } \\
\hline $\begin{array}{c}\text { Wk- } \\
16831\end{array}$ & 4 & & & $\begin{array}{l}3139 \\
\pm 36 \\
\end{array}$ & 1.9 & $2940-2790$ & $3030-2740$ & 2870 \\
\hline $\begin{array}{c}\text { Wk- } \\
15729\end{array}$ & 11 & & & $\begin{array}{r}3162 \\
\pm 34 \\
\end{array}$ & 3.0 & $2980-2820$ & $3060-2750$ & 2920 \\
\hline $\begin{array}{c}\text { Wk- } \\
37680\end{array}$ & 17 & & & $\begin{array}{c}3100 \\
\pm 23\end{array}$ & 3.1 & $2880-2750$ & $2960-2730$ & 2880 \\
\hline $\begin{array}{c}\text { Wk- } \\
37682\end{array}$ & 58 & & & $\begin{array}{c}3107 \\
\pm 23 \\
\end{array}$ & 3.8 & $2890-2760$ & $2960-2730$ & 2840 \\
\hline $\begin{array}{c}\text { Wk- } \\
37681\end{array}$ & 59 & & & $\begin{array}{c}2959 \\
\pm 22\end{array}$ & 2.7 & $2760-2650$ & $2800-2510$ & 2700 \\
\hline
\end{tabular}

${ }^{1}$ Results highlighted in grey are those that failed the yield tests

Table 3: Associated burial/Conus sp. shell ring combine results.

\begin{tabular}{|l|l|l|l|l|l|}
\hline $\begin{array}{l}\text { Burial } \\
\text { number }\end{array}$ & Lab number (bone/shell) & \multicolumn{2}{|c|}{ Diet 1 (-20/-10) } & \multicolumn{2}{c|}{ Diet 2 (-21/-12) } \\
\hline Burial 4 & (Wk-21019/Wk-16831) & $52 \%$ MarineC & $\mathrm{A}_{\text {comb }}=119.3$ & $69 \%$ MarineC & $\mathrm{A}_{\text {comb }}=106.9$ \\
\hline Burial 17 & (Wk-21026/Wk-37680) & $53 \%$ MarineC & $\mathrm{A}_{\text {comb }}=32.3$ & $70 \%$ MarineC & $\mathrm{A}_{\text {comb }}=79.2$ \\
\hline Burial 58 & (Wk-26341/Wk-37682) & $61 \%$ MarineC & $\mathrm{A}_{\text {comb }}=116.9$ & $78 \% \mathrm{MarineC}$ & $\mathrm{A}_{\text {comb }}=94.2$ \\
\hline Burial 59 & (Wk-26342/Wk-27681) & $56 \%$ MarineC & $\mathrm{A}_{\text {comb }}=54.6$ & $69 \% \mathrm{MarineC}$ & $\mathrm{A}_{\text {comb }}=108.6$ \\
\hline
\end{tabular}


Table 4: OxCal Modelled calibrated ages for the Teouma cemetery assuming a single-phase cemetery with Trapezoidal boundaries (results given at $68.2 \%$ prob.).

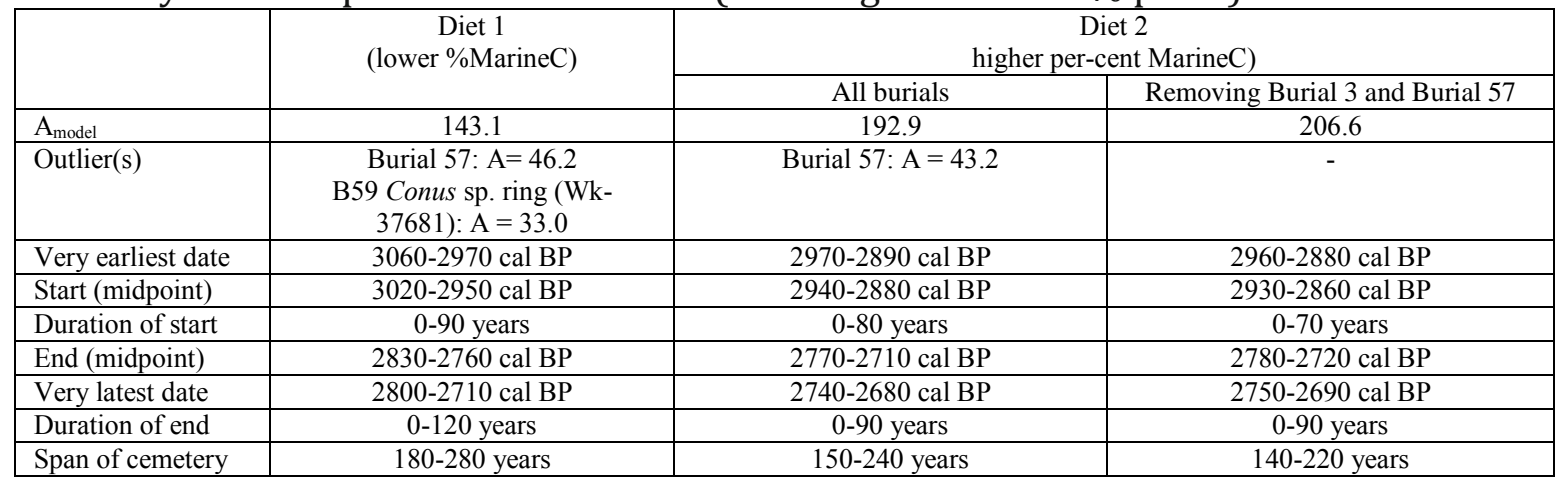

